\title{
Life sciences in zuidoost Nederland
}

Citation for published version (APA):

Fouarge, D., Blok, G. A., van Breugel, G. A. A., \& de Grip, A. (2008). Life sciences in zuidoost Nederland. Researchcentrum voor Onderwijs en Arbeidsmarkt, Faculteit der Economische Wetenschappen. ROA Reports No. 4 https://doi.org/10.26481/umarep.2008004

Document status and date:

Published: 01/01/2008

DOI:

10.26481/umarep.2008004

Document Version:

Publisher's PDF, also known as Version of record

\section{Please check the document version of this publication:}

- A submitted manuscript is the version of the article upon submission and before peer-review. There can be important differences between the submitted version and the official published version of record.

People interested in the research are advised to contact the author for the final version of the publication, or visit the DOI to the publisher's website.

- The final author version and the galley proof are versions of the publication after peer review.

- The final published version features the final layout of the paper including the volume, issue and page numbers.

Link to publication

\footnotetext{
General rights rights.

- You may freely distribute the URL identifying the publication in the public portal. please follow below link for the End User Agreement:

www.umlib.nl/taverne-license

Take down policy

If you believe that this document breaches copyright please contact us at:

repository@maastrichtuniversity.nl

providing details and we will investigate your claim.
}

Copyright and moral rights for the publications made accessible in the public portal are retained by the authors and/or other copyright owners and it is a condition of accessing publications that users recognise and abide by the legal requirements associated with these

- Users may download and print one copy of any publication from the public portal for the purpose of private study or research.

- You may not further distribute the material or use it for any profit-making activity or commercial gain

If the publication is distributed under the terms of Article $25 \mathrm{fa}$ of the Dutch Copyright Act, indicated by the "Taverne" license above, 


\title{
Life Sciences in Zuidoost Nederland
}

\author{
D. Fouarge \\ G. Blok \\ G. van Breugel \\ A. de Grip
}

ROA-R-2008/4 


\section{Colofon}

(C) Researchcentrum voor Onderwijs en Arbeidsmarkt (ROA). Niets uit deze uitgave mag op enige manier worden verveelvoudigd zonder voorafgaande schriftelijke toestemming van de directeur van het ROA.

Researchcentrum voor Onderwijs en Arbeidsmarkt

Faculteit der Economische Wetenschappen en Bedrijfskunde

Universiteit Maastricht

\section{Vormgeving}

ROA secretariaat, Maastricht

\section{Verkoop}

Researchcentrum voor Onderwijs en Arbeidsmarkt email: secretary@roa.unimaas.nl

website: www.roa.unimaas.nl

ISBN: 978-90-532I-470-I

november 2008 


\section{Inhoud}

Voorwoord

Samenvatting vii

I. Inleiding I

2. Het internationale aanbod in de Life Sciences 3

2.I Hoogopgeleiden in de Life Sciences 3

2.2 Arbeidsmarktperspectieven: werkloosheid en internationalisering 5

3. Life Sciences in Zuidoost Nederland: een enquête 9

3.I Beschrijving van het veldwerk 9

3.2 Respons IO

3.3 Kenmerken van de responderende organisaties IO

3.4 Kwalitatieve gesprekken II

3.5 Life Sciences II

4. Instroom en uitstroom $\quad$ I3

4.I Samenstelling personeelsbestand $\quad$ I3

4.2 Instroom van personeel $\quad$ I4

4.3 Uitstroom van personeel

5. Knelpunten op de arbeidsmarkt

5.I Knelpunten bij het zoeken naar personeel I9

5.2 Kwantitatief en kwalitatief tekort 2I

5.3 Verwachte uitstroom en instroom in de komende 5 jaar 22

$\begin{array}{ll}5.4 \text { Gebruikte wervingsinstrumenten } & 24\end{array}$

6. Vereiste competenties 29

6.I Disciplines nu en in de toekomst 29

6.2 Competenties nu en in de toekomst 32

6.3 Cursussen en training 35

6.4 Het verwerven van competenties $\quad 36$ 
7. Activiteiten, concurrentie ensamenwerking

7.I Activiteiten nu en in de toekomst

7.2 Concurrentie en samenwerking

Bijlage: aanvullende tabellen en figuren 


\section{Voorwoord}

Het project Regional Co-operation for Global Knowledge beoogt de samenwerking tussen bedrijven en kennisinstellingen bij de werving van kennismigranten voor de sector Life Sciences en medische technologie in Zuid-Limburg te verbeteren. Deze gezamenlijke aanpak zal de wervingskracht van de werkgevers in deze regio op dit segment van de arbeidsmarkt kunnen versterken. Het project wordt gedragen door bedrijven en kennisinstellingen in de regio. Ten behoeve van dit project is door het Researchcentrum voor Onderwijs en Arbeidsmarkt (ROA) en UNU-MERIT een gezamenlijk onderzoek uitgevoerd dat geresulteerd heeft in twee onderzoeksrapporten. Dit rapport is gericht op het in kaart brengen van de kwalitatieve en kwantitatieve aspecten van de vraag naar hoogopgeleide werknemers in de Life Sciences in de regio Zuidoost Nederland. In een daarop aansluitende studie van UNU-MERIT wordt dieper ingegaan op de strategieën voor de regionale ontwikkeling van Life Sciences (G. Duysters, C. Lemmens en R. Wintjens (2008) Regional cooperation for global knowledge: the policy part).

Het ROA wil een aantal personen dat aan de totstandkoming van dit rapport heeft meegewerkt bedanken. In de eerste plaats willen wij de leden van de projectgroep Regional Co-operation for Global Knowledge bedanken voor hun input: de heren G. Ensink (DSM), P. Keulers (TCZL), B. Keulen (VA), F. Bollen (LIOF), P. Borm (HsZ), R. Widdershoven (Provincie Limburg), R. Cournet (AZM), A. Postema (UM), M. Horsten (Pharmacell), S. Huntjens (UM) en Rob Meier (DSM). Met name Rob Meier is nauw betrokken geweest bij de begeleiding van dit project. Daarnaast willen wij Josee Herzberg (LifetecZONe) en Marjoke Kortas (CTMM) bedanken voor het beschikbaar stellen van adressenbestanden zonder welke dit onderzoek niet mogelijk was geweest. Jan Sauermann (ROA) willen wij bedanken voor zijn bijdrage aan het opstellen van de internetenquête onder Life Sciences organisaties. Ten slotte willen wij de gesprekspartners uit het MKB, grote bedrijven en kennisinstellingen bedanken die door middel van diepte interviews hebben geholpen vorm te geven aan de enquête onder Life Sciences organisaties in Zuidoost Nederland en kleur en duiding hebben gegeven aan de onderzoeksresultaten. 



\section{Samenvatting}

De vraag naar kenniswerkers in de Life Sciences is hoog. Dit geldt zowel op internationaal, nationaal als regionaal niveau. In dit rapport wordt ingegaan op de kwalitatieve en kwantitatieve aspecten van de vraag naar hoogopgeleide werknemers in de Life Sciences in de regio Zuidoost Nederland. Dit wordt langs een tweetal wegen gedaan. Ten eerste heeft er een verkenning plaatsgevonden van de arbeidsmarktinstroom van werknemers in de Life Sciences in internationaal vergelijkend perspectief. Ten tweede, omdat er op dit punt weinig gegevens beschikbaar zijn, is besloten om voor dit project data te verzamelen onder organisaties die actief zijn op het terrein van de Life Sciences in Zuidoost Nederland. Zowel voor als na de enquête is een beperkt aantal organisaties benaderd voor gestructureerde kwalitatieve interviews. De interviews voor de enquête hebben gediend om relevante enquêtevragen te formuleren. De interviews na de enquête hebben gediend om de bevindingen uit het onderzoek beter te kunnen duiden en verbijzonderen.

\section{Arbeidsmarktinstroom van werknemers in de Life Sciences}

Volgens internationale gegevens stijgt het opleidingsniveau van schoolverlaters: steeds meer jongeren beginnen op de arbeidsmarkt als een hoogopgeleide. Deze groei is ook te merken in het aantal afgestudeerden met een achtergrond in de Life Sciences of daaraan gerelateerde disciplines. Echter, in vergelijking met sommige andere landen, heeft Nederland relatief minder afgestudeerden in de Life Sciences. De arbeidsmarktperspectieven voor Life Sciences werknemers zijn zonder meer gunstig. De kans op werkloosheid is lager dan voor andere beroepen en de kans op een aantrekkelijke baan in het buitenland is groot. Voor een land als Nederland is het de kunst om de potentiële migranten aan te trekken voordat zij elders naartoe gaan. Daarbij zijn het aanbieden van een aantrekkelijk studieprogramma of een stage tijdens de studie een manier om buitenlandse Life Sciences werknemers aan te trekken.

\section{Hoogopgeleide werknemers in de Life Sciences in Zuidoost Nederland}

Omdat er relatief weinig bekend is over werknemers in de Life Sciences in de regio Zuidoost Nederland, is besloten om voor dit project informatie te verzamelen onder organisaties die actief zijn op dit terrein. Daartoe is in de zomer van 2008 een enquête uitgezet. Zowel kennisinstellingen als grote bedrijven en het MKB zijn benaderd voor 
deelname aan de enquête. In de enquête is niet alleen ingegaan op de huidige stand van zaken, maar ook op de toekomstverwachtingen voor de komende vijf à tien jaar. Kwalitatieve gesprekken met belangrijke spelers hebben geholpen de enquête vorm te geven. Daarnaast zijn enkele belangrijke bevindingen uit de enquête met een viertal geselecteerde organisaties besproken. Uit de enquête blijkt dat organisaties in de Life Sciences relatief veel werknemers op HBO of academisch niveau in dienst hebben. Maar liefst driekwart van het personeel is hoogopgeleid, al is dit percentage lager in het MKB. De organisaties zijn bovendien behoorlijk internationaal georiënteerd: ongeveer tweederde heeft personeel in dienst dat afkomstig is uit het buitenland. Daarbij gaat het doorgaans om personeel uit een (naburig) ander EU land.

In het afgelopen jaar is het aantal hoogopgeleide werknemers (HBO en academisch) dat werkzaam is bij een Life Sciences organisatie in Zuidoost Nederland toegenomen. De verwachting is bovendien dat de vraag in de komende vijf jaar verder zal toenemen. De vraag naar Life Sciences werknemers op MBO niveau zal daarentegen, naar verwachting, in de komende vijf jaar min of meer stabiel blijven. De meeste organisaties hebben momenteel geen probleem met de werving van werknemers op $\mathrm{MBO}$ niveau en ervaren ook geen tekort (kwalitatief of kwantitatief) aan MBO'ers. Organisaties die wel een tekort aan MBO'ers ervaren zijn vooral bedrijven in het MKB. De kennisinstellingen, maar ook grote bedrijven, blijken echter wel problemen te ervaren met de werving van hoogopgeleide werknemers in de Life Sciences. Zij ervaren ook vaker een (kwalitatief en/of kwantitatief) tekort aan hoogopgeleide werknemers in de Life Sciences dan het MBK

Het gepercipieerde tekort aan hooggeschoolden lijkt vooral betrekking te hebben op de toekomstverwachtingen. Uit kwalitatieve gesprekken rond het tekort aan personeel zeggen de gesprekspartners het volgende: "We kunnen nog steeds veel mensen krijgen"; "Veel mensen reageren op vacatures"; "Tot nu toe geen klachten gehad om mensen te vinden". Echter, de veroudering van het personeelsbestand en de snelle groei van sommige organisaties baart zorgen voor de toekomst: "Op dit moment begint het wel lastig te worden om echte specialisten te vinden".

\section{Verwachte uitstroom en werving}

Van alle organisaties verwacht tweederde dat een deel van de hoogopgeleide werknemers in de Life Sciences in de komende vijf jaar zal vertrekken. De uitstroom komt gemiddeld uit op een kwart van het totaal aantal hoogopgeleide werknemers. Onder kennisinstellingen is de verwachte uitstroom groter dan in het MKB. Dit geldt zowel voor het aantal organisaties die uitstroom verwachten, als voor het gemiddelde percentage werknemers dat per organisatie uitstroomt. Bij de kennisinstellingen wordt dit mogelijk veroorzaakt door het grote aantal tijdelijke contracten, onder andere voor aio's en postdocs. Er is sprake van een hoog verloop van hoogopgeleide Life Sciences werknemers. Het lijkt er dan ook op dat de vervangingsvraag de komende jaren sterk 
zal toenemen. Dit wijst er op dat het van belang is om te zorgen voor voldoende aanwas van studenten in de Life Sciences.

Organisaties die actief zijn in de Life Sciences blijken vooral te werven via het eigen personeel of het eigen netwerk: "Of je mensen kan vinden hangt erg veel van connecties af, mensen komen mee in de slipstream van anderen.” Deze wervingsmethode wordt ook als effectief ervaren. Andere, meer traditionele wervingskanalen zoals advertenties, uitzendbureaus en commerciële wervingsbureaus worden minder vaak gebruikt en ook als minder effectief (en duurder) beoordeeld. Grote bedrijven gebruiken deze traditionele wervingsinstrumenten overigens wel vaker dan het MKB en kennisinstellingen.

Ook al wordt er niet vaak personeel in het buitenland geworven, de bereidheid om dit te doen is wel groot. Daarbij is het opvallend dat de bereidheid om te werven in de buurlanden Duitsland en België het grootst is. De bereidheid om in OostEuropa en Azië te werven lijkt minder groot. Opvattingen over culturele verschillen en verschillen die betrekking hebben op communicatieve vaardigheden lijken hierbij een rol te spelen. Bedrijven in het MKB lijken overigens minder bereid te zijn om in het buitenland te werven dan grote bedrijven en kennisinstellingen.

\section{Vraag naar bepaalde opleidingsachtergronden}

De opleidingsachtergronden van hoogopgeleide werknemers in de Life Sciences waar momenteel de grootste vraag naar is, zijn de vakgebieden biomedisch, biotechnologie (inclusief moleculaire biologie) en biochemie. Bij de grote bedrijven is ook chemie een vaak gevraagde opleidingsachtergrond. Ook in de komende vijf jaar zullen de organisaties aan deze disciplines de meeste behoefte hebben. Daarnaast zijn er enkele specifieke opleidingsachtergronden waar niet veel vraag naar is, maar waarvan de betreffende organisaties aangeven er niet zonder te kunnen. Het gaat om disciplines als chemische analyse, polymeerchemie, biometrie, natuurkunde en plantkunde.

Het is opmerkelijk dat het beeld van de relevante disciplines in het MKB erg divers is. MKB bedrijven die uit een lijst van I6 disciplines in de Life Sciences konden aangeven welke discipline voor hen het meest relevant waren, kozen vaker voor de categorie 'anders'. Dit duidt er op dat de vraag in het MKB meer divers van aard is, met veel kleine bedrijven die medewerkers zoeken met zeer specifieke kennis. Ook als het gaat om de vraag aan welke disciplines er in de komende vijf jaar de meeste of juist de minste behoefte zal zijn kruisen MKB bedrijven vaker de categorie 'anders' of 'daar heb ik momenteel geen zicht op' aan.

\section{Competenties van Life Sciences werknemers nu en in de toekomst}

De vraag naar mensen met een bepaalde opleidingsachtergrond geeft een indicatie van de vraag naar bepaalde vakinhoudelijke competenties en hoe deze vraag zich de 
komende jaren zal ontwikkelen. Vanzelfsprekend zijn vakspecifieke vaardigheden onontbeerlijk voor een baan in de Life Sciences. Daarnaast zijn er ook meer algemene competenties nodig. In de enquête ook ingegaan op deze algemene competenties. Op dit moment blijken hoogopgeleide werknemers in kennisinstellingen vooral te beschikken over competenties als fundamenteel onderzoek kunnen doen, vermogen om te leren, kennis kunnen delen, zelfstandigheid, probleemoplossend vermogen en ambitie. In grote bedrijven zijn de hoogopgeleide werknemers vooral goed in het doen van toegepast onderzoek, zelfstandig werken en hebben ze het vermogen om verder te leren. In het MKB werken op dit moment vooral hoogopgeleide werknemers die een hoog lerend en probleemoplossend vermogen hebben en goed in teamverband kunnen werken.

Een vergelijking tussen de organisaties wat betreft de vraag naar algemene competenties in de komende vijf jaar levert enkele interessante bevindingen op. Zo verwachten kennisinstellingen meer behoefte te hebben aan werknemers die toegepast onderzoek kunnen doen en projecten kunnen organiseren en managen: "We zoeken mensen die niet te braaf zijn, die kennis willen verspreiden en die nieuwe kennis willen genereren, ... Mensen moeten echter wel in staat zijn om goed uit te kunnen leggen waar ze mee bezig zijn". Bovendien moet dit creatieve en innovatieve mensen zijn. Grote bedrijven denken vooral behoefte te hebben aan competenties als ondernemerschap en flexibiliteit: "Mensen met managementpotentieel". Bedrijven in het MKB verwachten meer behoefte te hebben aan competenties zoals toegepast onderzoek kunnen doen, organiseren en managen van projecten, en vooral ook commercieel inzicht. Het MKB zoekt naar "pragmatisch ingestelde werknemers" met een goed "probleemoplossend vermogen". Al met al lijken organisatie op zoek te zijn naar duizendpoten, die alle gewenste competenties bezitten. Men beseft echter ook dat een dergelijke duizendpoot nauwelijks bestaat ("De droomstudent bestaat niet").

Wanneer gekeken wordt naar de cursussen die door hoogopgeleide werknemers in de Life Sciences gevolgd worden, blijken deze vooral gericht te zijn op communicatieve vaardigheden en het organiseren en managen van projecten. Voor de meeste competenties, afgezien van fundamenteel onderzoek kunnen doen en in minder mate toegepast onderzoek kunnen doen, wordt aangegeven dat de algemene competenties vooral on-the-job te leren zijn. Dit on-the-job leren kan gebeuren via formele training, learning by doing of het leren van collega's.

\section{Activiteiten van organisaties in de Life Sciences nu en in de toekomst}

Als gekeken wordt naar de verwachte ontwikkelingen in de aard van de activiteiten van organisaties in de Life Sciences, dan zijn er duidelijke accentverschuivingen te zien. Kennisinstellingen hebben nu hun activiteiten vooral gericht op fundamenteel onderzoek en verwachten in de komende vijf jaar dat de activiteiten meer op toegepast onderzoek gericht zullen zijn dan nu het geval is. De activiteiten in grote bedrijven zijn nu reeds vooral gericht op toegepast onderzoek. In de komende vijf jaar 
wordt er nog meer nadruk hierop verwacht. Ook verwachten grote bedrijven dat er de komende jaren meer nadruk komt te liggen op clinical trials. Het MKB zal zich de komende vijf jaar meer richten op marketing, verkoop en service en ook op toegepast onderzoek.

Deze accentverschuivingen in de activiteiten voor de komende vijf jaar zal zich naar verwachting doorzetten in de jaren daarna, ook al geeft ongeveer $20 \%$ van de organisaties aan niet goed te weten hoe de ontwikkeling in de komende tien jaar zal zijn. Dit toont aan dat de Life Sciences sector te maken heeft met een grote onzekerheidsmarge ten aanzien van de middenlange termijn.

Ook is het voor veel organisaties onzeker of bepaalde activiteiten in de komende vijf of tien jaar al dan niet worden verplaatst naar een andere regio of een ander land. Het is niet duidelijk wat organisaties op dit punt van plan zijn om te doen. Wel lijkt het er op dat het fundamenteel onderzoek, voor zover organisaties dit nu al doen, in de regio Zuidoost Nederland zal blijven. Voor andere activiteiten bestaat de kans dat deze naar een andere regio of een ander land verplaatst zullen worden.

\section{Samenwerking nu en in de toekomst}

Organisaties kunnen samenwerking aangaan met elkaar, met kennisinstellingen of met de regionale overheid als het gaat om Research \& Development (R\&D), personeel en training en strategiebepaling. Momenteel wordt er vooral samengewerkt op het terrein van $R \& D$, oftewel het open innoveren. Daarentegen is er veel minder samenwerking op de andere terreinen. Een gesprekspartner illustreert het grote belang van het open innoveren: "Je kunt niet meer alleen dit soort onderzoek doen, de ontwikkelingen gaan razendsnel en op topniveau moet je samenwerken. Je wordt er altijd beter van". Het MKB wijst ook op de voordelen van samenwerking op het terrein van een arbeidspool: "Wat ik belangrijk vind is dat we beginnen met een arbeidspool, zodat we niet elkaars personeel afsnoepen”.

De bereidheid om in de komende vijf jaar meer samen te gaan werken dan nu het geval is, is vooral bij kennisinstellingen en het MKB aanwezig. Grote bedrijven zijn vaker van mening dat zij het zelf kunnen doen en staan sceptischer tegenover de rol van de provincie. Een mogelijke reden is het gevoel dat de samenwerking te weinig oplevert. Kennisinstellingen en het $\mathrm{MKB}$ vinden juist dat grote bedrijven te weinig initiatief tonen. Het is dan ook een uitdaging voor de toekomst om de vele verschillende actoren op het gebied van Life Sciences bij elkaar te brengen, zeker met het oog op de diversiteit van hun belangen en visies. 



\section{Inleiding}

De internationale vraag naar hoogopgeleide kenniswerkers in de Life Sciences is hoog. De regio Zuidoost Nederland wenst zich te profileren als een groeiregio voor Life Sciences, en zal daarom met deze internationale component van de arbeidsmarkt voor kenniswerkers te maken krijgen. In dat verband is het van groot belang om goed inzicht te hebben in de ontwikkeling van de regionale behoefte aan kenniswerkers in de Life Sciences. Ten behoeve van dit onderzoeksproject zijn twee studies uitgevoerd. In deze studie wordt ingegaan op de kwantitatieve en kwalitatieve behoefte aan kenniswerkers in de Life Sciences. In een andere studie door UNU-MERIT wordt dieper ingegaan op de strategieën voor de regionale ontwikkeling van Life Sciences (G. Duysters, C. Lemmens en R. Wintjens (2008) Regional cooperation for global knowledge: the policy part).

De beschikbare databronnen zijn niet toereikend om op basis van een economisch model of trendanalyses een prognose te maken van de toekomstige behoefte aan kenniswerkers in de Life Sciences in Zuidoost Nederland. Om die reden is besloten om in de zomer van 2008 een enquête te houden onder de relevante organisaties: kennisinstellingen, grote bedrijven en het MKB. In de enquêtes is gevraagd naar:

- de lange termijn visie op de verwachte arbeidsmarktbehoefte (het ambitieniveau),

- de verwachte ontwikkeling van de werkgelegenheid en de vervangingsbehoefte in de komende vijf jaar,

- het huidige aantal vacatures,

- het aantal werkzame buitenlanders,

- de gevraagde competenties en

- de wervingsstrategie.

De kwantitatieve resultaten van deze enquête relateren we aan een kwalitatief onderzoek onder een aantal geselecteerde bedrijven.

Het aantrekken van hoogopgeleide werknemers in de Life Sciences zal gezien de grote internationale concurrentie bijzondere wervingsinspanningen vergen. Daarom heeft er in een andere studie door UNU-MERIT een inventarisatie plaatsgevonden van strategieën voor de regionale ontwikkeling van Life Sciences en kritische succesfactoren voor regionale innovatie. In dat rapport wordt vanuit de literatuur en vanuit huidige activiteiten en beleidsinstrumenten van ondernemingen, clusterorganisaties, kennisinstellingen en lokale overheden een overzicht gegeven van best practices uit 
andere toonaangevende regio's om kenniswerkers in Life Sciences aan te trekken en te behouden. Daarbij worden de effectiviteit van deze activiteiten en de beleidsimplicaties nader belicht. Bovendien wordt naar het fenomeen clusterontwikkeling gekeken. Uiteindelijk worden er aanbevelingen gedaan voor de ontwikkeling van het Life Sciences cluster in Zuidoost Nederland, en het aantrekken en behouden van talent.

\section{Opbouw van dit rapport}

In hoofdstuk 2 wordt een beeld geschetst van het internationale aanbod van kenniswerkers op het gebied van Life Sciences. Het veldwerk voor de kwantitatieve en kwalitatieve enquêtes onder Life Sciences organisaties in Zuidoost Nederland wordt in hoofdstuk 3 beschreven. Ook wordt een overzicht van de respons gegeven. In hoofdstuk 4 wordt een beeld geschetst van de instroom en uitstroom van Life Sciences werknemers. Knelpunten op de arbeidsmarkt voor de Life Sciences en de personeelswerving komen aan bod in hoofdstuk 5. Hoofdstuk 6 gaat in op de vereiste vakinhoudelijke kennis en algemene competenties van hoogopgeleide Life Sciences werknemers nu en in de komende vijf jaar. In hoofdstuk 7 komen de activiteiten van Life Sciences bedrijven en werknemers aan bod en de verwachte veranderingen daarin in de komende vijf à tien jaar. In dit hoofdstuk wordt ook ingegaan op samenwerking (en de bereidheid daartoe) tussen Life Sciences organisaties op het terrein van R\&D, personeel en strategiebepaling voor de toekomst. 


\section{Het internationale aanbod in de Life Sciences}

Hoewel internationale statistische instanties zoals de OESO en Eurostat in toenemende mate gegevens publiceren over Life Sciences werknemers en afgestudeerden is de definitie van Life Sciences zelf niet altijd eenduidig. In sommige bronnen zijn de Life Sciences terug te vinden onder de kop van 'human resources employed in science and technology' of 'Science and Engineering' (Eurostat). In andere publicaties worden Life Sciences wel duidelijker onderscheiden. In dit hoofdstuk gaan wij in op het internationale aanbod van werknemers in de Life Sciences. Wij gaan met name in op gegevens rond het aantal afgestudeerden in de Life Sciences en motieven achter het migratiegedrag van afgestudeerden op het terrein van Life Sciences.

\subsection{Hoogopgeleiden in de Life Sciences}

Het stimuleren van de keuze van jongeren voor een carrière in de 'Science and Technology' wordt door veel OESO landen nagestreefd. Uit een recente studie door Eurostat blijkt dat een substantieel aantal hoogopgeleide Europese werknemers werkzaam is in de sector 'Science and Technology': ruim 59 miljoen werknemers waren in 2006 werkzaam in de sector. ${ }^{.}$Ongeveer 18 procent van deze groep behoort tot de 'Scientists and Engineers' (S\&E), een subgroep die personen omvat in de beroepen 'Specialisten in de fysische, wiskundige en technische wetenschappen' (ISCO code 2I) en 'Specialisten in de medische en biowetenschappen' oftewel Life Sciences (ISCO code 22). Echter, ook in de 'Science and Technology' slaat de vergrijzing toe, zij het minder snel dan in de rest van de economie. Gemiddeld genomen is het aantal oudere werknemers als percentage van het totaal aantal werkenden in de 'Science and Technology' in de afgelopen tien jaar toegenomen. ${ }^{2}$ In de EU was in $200625 \%$ van de werknemers in de sector 'Science and Technology' tussen de 50 en 64 jaar. In andere sectoren was dit gemiddeld genomen $26 \%$. In Nederland is het percentage werknemers tussen de 50 en 64 jaar ongeveer gelijk aan het Europese gemiddelde.

I. Meri, T. (2008). Human Resources employed in Science and Technology Occupations. Science and Technology Statistics in Focus 77/2008.

2. In Nederland, bijvoorbeeld, is het aandeel werknemers in de 'Science and Technology' ouder dan 45 jaar toegenomen van 33\% in 1996 naar $43 \%$ in 2006 (berekeningen op basis van http://ec.europa. eu/eurostat). 
Tabel 2.1

Afgestudeerden hoger onderwijs in de Life Sciences (aantal en procentuele groei)

\begin{tabular}{|c|c|c|c|}
\hline & 1998 & 2006 & $\begin{array}{r}\text { Groei } \\
\%\end{array}$ \\
\hline Australië & 9.162 & 8.000 & -13 \\
\hline Oostenrijk & - & 1.236 & \\
\hline België & - & 1.798 & \\
\hline Canada & 8.469 & 9.099 & 7 \\
\hline Tsjechië & 256 & 991 & 287 \\
\hline Denemarken & - & 782 & \\
\hline Finland & 389 & 528 & 36 \\
\hline Frankrijk & - & 16.637 & \\
\hline Duitsland & 5.977 & 9.666 & 62 \\
\hline Griekenland & - & - & \\
\hline Hongarije & 244 & 366 & 50 \\
\hline IJsland & 65 & 95 & 46 \\
\hline lerland & 1.529 & - & \\
\hline Italië & 9.306 & 12.435 & 34 \\
\hline Korea & 4.240 & 9.757 & 130 \\
\hline Mexico & - & 4.837 & \\
\hline Nederland & 839 & 1.020 & 22 \\
\hline Nieuw Zeeland & 118 & 1.715 & 1.353 \\
\hline Noorwegen & 305 & 577 & 89 \\
\hline Polen & - & 10.299 & \\
\hline Portugal & - & 1.506 & \\
\hline Slowakije & - & 964 & \\
\hline Spanje & 4.439 & 4.582 & 3 \\
\hline Zweden & 1.614 & 1.445 & -11 \\
\hline Zwitserland & 934 & 1.440 & 54 \\
\hline Turkije & 2.230 & 3.806 & 71 \\
\hline Verenigd Koningrijk & 16.015 & 20.181 & 26 \\
\hline Verenigde Staten & 75.253 & 83.634 & 11 \\
\hline
\end{tabular}

Het aantal hoogopgeleiden (afgestudeerden uit het hoger onderwijs) stijgt snel in de meeste OESO landen. Bijvoorbeeld, Nederland telde in 199882.995 afgestudeerden op tertiair niveau. In 2006 waren er 117.392 afgestudeerden, oftewel $41 \%$ meer. $^{3}$ Echter, Nederland heeft relatief minder afgestudeerden in de Life Sciences dan Europa: $15,2 \%$ van de Nederlandse afgestudeerden valt in de categorie "Maths, Science and Technology fields" ${ }^{4}$ terwijl 22,4\% van de EU-afgestudeerden tot deze categorie behoort. De categorie "Maths, Science and Technology fields" is echter veel breder dan Life Sciences. Om die reden wordt in tabel 2.I dieper ingegaan op het aantal afgestudeerden in de Life Sciences van een aantal OESO landen. Daarnaast wordt een

3. Zie http://stats.oecd.org/wbos/Index.aspx

4. Zie http://ec.europa.eu/eurostat; Science and technology; Human Resources in Science \& Technology. 
ontwikkeling van deze aantallen in de tijd gegeven. De tabel laat zien dat Nederland in 2006 I.020 afgestudeerden in de Life Sciences telde tegenover 839 afgestudeerden in 1998 . Dit houdt een groei in van bijna $22 \%$. Ondanks deze groei laat de tabel ook zien dat het aantal Nederlandse afgestudeerden in de Life Sciences kleiner is dan in de buurlanden Duitsland en België. Dit laatste is opmerkelijk omdat België jaarlijks minder afgestudeerden heeft dan Nederland. Al met al laat de tabel zien dat er zeker een internationaal aanbod is van hoogopgeleide Life Sciences werknemers en dat dit aanbod in de meeste landen groeit.

\subsection{Arbeidsmarktperspectieven: werkloosheid en internationalisering}

De arbeidsmarktperspectieven voor Life Sciences werknemers in de EU zijn betrekkelijk gunstig. Van de arbeidskrachten met een achtergrond in de sector 'Science and technology' is slechte 3,2\% werkloos. Voor andere sectoren is dit $9,5 \%$.

Bovendien kent de sector een zekere mate van internationalisering: 4,9\% van de EU werknemers in de sector 'Science and technology' is in een ander land geboren dan het land waar hij of zij momenteel werkt.' De migratie van afgestudeerden in de Life Sciences kan nader onderzocht worden aan de hand van de REFLEX enquête. ${ }^{6}$ REFLEX bevat informatie over de arbeidsmarktpositie van hoger opgeleiden vijf jaar na afstuderen in vijftien Europese landen. De enquête is in 2006 gehouden onder afgestudeerden uit het hoger beroepsonderwijs en het wetenschappelijk onderwijs. De respondenten zijn afgestudeerd in het academisch jaar 1999/2000. De REFLEX data maken het mogelijk om op basis van opleidingsniveau en -richting afgestudeerden in de Life Sciences te identificeren. Life Sciences afgestudeerden kunnen dan vergeleken worden met de afgestudeerden van andere studierichtingen. REFLEX bevat informatie over het salaris, de functie en de organisatie waarin men op het moment van enquêteren werkzaam is. Ook bevat REFLEX informatie over de tevredenheid met de eerste baan na afstuderen en met de baan op het moment van enquêteren, ongeveer vijf jaar na afstuderen. Ook is bekend of men werkzaam is in een ander land dan het land waar men gestudeerd heeft, in de eerste dan wel de huidige baan.

In tabel 2.2 wordt een overzicht gegeven van het percentage afgestudeerden in de Life Sciences dat direct na de studie in het buitenland is gaan werken of dat voor de huidige baan in het buitenland werkt. Daaruit is af te leiden dat de kans op migratie in de meeste landen groter is voor afgestudeerden in de Life Sciences dan voor afgestudeerden in andere disciplines. Dit geldt overigens niet voor het Verenigd Koningrijk. Bij uitstek is dat een land met relatief gunstige arbeidsmarktperspectieven voor Life Sciences werknemers. De conclusie is dat Life Sciences afgestudeerden bereid zijn om

5. Alle cijfers hebben betrekking op het jaar 2006 en zijn afkomstig uit Eurostat (2008). Science, technology and innovation in Europe. Luxembourg: Office for Official Publications of the European Communities.

6. Voor aanvullende informatie over de data, zie: http://www.fdewb.unimaas.nl/roa/reflex/ 
het eigen land te verlaten. De vraag, voor een land als Nederland, is alleen: hoe trek je deze potentiële migranten aan?

\section{Tabel 2.2}

Percentage afgestudeerden dat naar een ander land gemigreerd is in de eerste of huidige baan, naar afstudeerrichting

\begin{tabular}{lrr} 
& \multicolumn{2}{c}{ Migratie voor eerste of huidige baan } \\
Oostenrijk & Life Sciences & Andere studie \\
België & 15 & 9 \\
Tsjechië & 4 & 3 \\
Finland & 2 & 2 \\
Frankrijk & 2 & 3 \\
Duitsland & 6 & 4 \\
Italië & 4 & 2 \\
Nederland & 2 & 2 \\
Noorwegen & 4 & 2 \\
Portugal & 0 & 1 \\
Spanje & 1 & 1 \\
Zwitserland & 4 & 3 \\
Verenigd Koninkrijk & 4 \\
Bron: REFLEX & 4 & 2 \\
\hline
\end{tabular}

De REFLEX data lenen zich ook voor een analyse van de determinanten van migratie van afgestudeerden. In tabel 2.3 worden de kernbevindingen uit analyses van de migratiekeuzen van S\&E afgestudeerden (waar de Life Sciences toe behoren) in hun eerste of hun huidige baan. Bij de analyses wordt een onderscheid gemaakt tussen de volgende migratiekeuzen: niet migreren, migreren naar continentaal Europa of migreren naar Angelsaksische landen (VK, VS, Canada, Australië). Een hoog loon en aantrekkelijke arbeidsmarktperspectieven zoals een hoge intensiteit van uitgaven aan $\mathrm{R} \& \mathrm{D}^{7}$ in een land of regio zijn mogelijke motieven voor de migratiekeuze van jonge S\&E afgestudeerden. De determinanten zijn niet hetzelfde voor de verschillende bestemmingen. Bij migratie naar het Europees continent speelt vooral het loon een belangrijke rol. Bij migratie naar Angelsaksische landen gaat het vooral om arbeidsmarktperspectieven (hoge intensiteit van $R \& D$ ). Voor beide bestemmingen geldt dat migranten geselecteerd worden op basis van hun goede studieresultaat.

De analyses laten nog meer zien. Omdat ervaring met migratie in het verleden een belangrijke voorspeller is voor toekomstige migratie, kan geconcludeerd worden dat het van belang is om afgestudeerden vroeg aan zich te binden. Deze binding kan tot stand worden gebracht door het aanbieden van een aantrekkelijk studieprogramma in het buitenland of een buitenlandse stage tijdens de studie. Dit geldt zeker voor een land als Nederland.

7. Uitgaven aan R\&D als percentage van GDP. 



\section{Life Sciences in Zuidoost Nederland: een enquête}

\subsection{Beschrijving van het veldwerk}

Om aan de informatiebehoefte te voorzien voor dit onderzoeksproject is in juni 2008 een enquête uitgezet onder arbeidsorganisaties die actief zijn op het terrein van Life Sciences in Zuidoost Nederland (de ROA Life Sciences Survey). De vragenlijst is uitgezet onder organisaties die aangesloten zijn bij LifetecZONe en de programma's BMM, CTMM en INTACT. De benaderde respondenten zijn directeuren van grote en MKB bedrijven en onderzoeksleiders bij grote bedrijven of kennisinstellingen in Zuidoost Nederland. Om de vragenlijst op een efficiënte manier en op relatief korte termijn uit te kunnen zetten zijn de benaderde personen per e-mail uitgenodigd om de vragenlijst in te vullen. De contactgegevens zijn verkregen dankzij de samenwerking van LifetecZONe (96 adressen) en het onderzoeksprogramma CTMM (236 adressen) en via (in)formele contacten van ROA. Het is belangrijk om te benadrukken dat bij grote bedrijven en grote kennisinstellingen zoals de Universiteit Maastricht meerdere personen benaderd zijn voor deelname aan de enquête.

De verstuurde e-mail bevatte een toelichting over het belang van de enquête, een toelichting op de enquête en een link naar de online vragenlijst. ${ }^{I}$ De vragenlijst spitste zich toe op kwalitatieve en kwantitatieve aspecten van de vraag naar hoogopgeleide werknemers in de Life Sciences. Niet alleen werd ingegaan op de huidige situatie en behoeften, maar de behoefte en wensen voor de komende vijf à tien jaar kwamen nadrukkelijk aan bod in de enquête.

Voorafgaand aan de enquête zijn gesprekken gevoerd met sleutelpersonen op het terrein van Life Sciences zoals met de programmaleiders van BMM, INTACT en CTMM, enkele directeuren van MKB bedrijven en leidinggevenden bij onderzoek en strategie afdelingen van grote bedrijven en kennisinstellingen. De uitkomsten uit deze gesprekken zijn gebruikt voor de precieze invulling van de vragenlijst.

I. Om redenen van privacy zijn de e-mails aan respondenten die aangesloten zijn bij LifetecZONe verstuurd vanuit een e-mail adres van LifetecZONe. 


\subsection{Respons}

Op I7 en I8 juni 2008 zijn de eerste uitnodigingen per e-mail verstuurd. Daarna zijn er op 25 juni, 2 juli en 13 augustus herinneringen verstuurd. Het veldwerk is begin september afgesloten. Tabel 3.I geeft een overzicht van de ontwikkeling van de respons op de enquête. 26 van de 340 uitnodigingen, die in juni per e-mail zijn verstuurd, bleken niet bezorgbaar door een incorrect e-mailadres. Dit betekent dat $3 \mathrm{I} 4$ personen de uitnodiging voor deelname hebben ontvangen. $\mathrm{Na}$ drie herinneringen was de respons gelijk aan $31 \%$. Dit betekent dat 97 respondenten aan de enquête zijn begonnen. Daarvan hebben 67 respondenten de enquête afgemaakt. De respons is hiermee vergelijkbaar met de respons in andere bedrijfsenquêtes. Echter, gelet op de kleine aantallen is voorzichtigheid geboden bij een gedetailleerde opsplitsing van de resultaten naar achtergrondkenmerken.

Tabel 3.1

Respons op ROA Life Sciences Survey (aantallen)

$\begin{array}{lrr}\text { Verstuurde uitnodigingen op } 17 \text { en } 18 \text { juni } & 340 & \\ \text { Niet bezorgbare e-mails } & 26 & \text { Waarvan afgemaakt } \\ \text { Steekproefomvang } & 314 & 21 \\ & \text { Begonnen } & 37 \\ 25 \text { juni, voor } 7^{\text {ste }} \text { herinnering } & 28 & 50 \\ 30 \text { juni, voor } 2^{\text {de }} \text { herinnering } & 53 & 53 \\ 15 \text { juli } & 71 & 67 \\ 13 \text { augustus, voor } 3^{\text {de }} \text { herinnering } & 74 & 21 \% \\ \text { September (einde veldwerk) } & 97 & (68 \% \text { van personen die begonnen zijn aan } \\ \text { Responspercentage } & 31 \% & \text { de enquête) }\end{array}$

Omdat niet precies duidelijk was welke functie de benaderde respondent bekleedde in de organisatie is een vraag aan de vragenlijst toegevoegd die bepalend was voor de formulering van het vervolg van de vragen. Met deze vraag werd geprobeerd om de beste invalshoek bij de formulering van de vragen te bepalen. Aan de respondenten is gevraagd op welk niveau zijn of haar verantwoordelijkheden lagen: het bedrijf als geheel ( $43 \%$ van de respondenten), een afdeling van het bedrijf ( $52 \%$ van de respondenten) of een vestiging van het bedrijf ( $5 \%$ van de respondenten).

\subsection{Kenmerken van de responderende organisaties}

Op basis van de domeinnamen behorend bij de e-mailadressen van de respondenten is vervolgens een indeling van de organisaties gemaakt die in het vervolg van dit rapport zal worden gebruikt. De indeling maakt een onderscheid tussen kennisinstellingen, grote bedrijven en MKB. Tabel 3.2 geeft aan hoe de respondenten verdeeld zijn naar 
soort organisaties. $44 \%$ van de respondenten zijn betrokken bij een $\mathrm{MKB}, 29 \%$ bij een groot bedrijf en $27 \%$ bij een kennisinstelling.

Tabel 3.2

Classificatie van soorten organisaties in de enquête (aantallen en percentages)

\begin{tabular}{|c|c|c|}
\hline & Aantal & Percentage \\
\hline Kennisinstellingen ${ }^{\mathrm{a}}$ & 26 & 27 \\
\hline Grote bedrijven ${ }^{\mathrm{b}}$ & 28 & 29 \\
\hline MKB & 43 & 44 \\
\hline $\begin{array}{l}\text { Totaal } \\
\text { Kennisinstellingen: onderzoeksgroepen van de } \\
\text { AZM } \\
\text { Grote bedrijven: DSM, Philips, Organon, CTMM }\end{array}$ & $\begin{array}{l}97 \\
\text { t, TU Ein }\end{array}$ & $\begin{array}{c}100 \\
\text { ool Zuyd, RO }\end{array}$ \\
\hline
\end{tabular}

\subsection{Kwalitatieve gesprekken}

Zoals gezegd is de vragenlijst voor de enquête tot stand gekomen tegen de achtergrond van de kwalitatieve gesprekken met sleutelfiguren op het terrein van Life Sciences. In kwalitatieve gesprekken zijn na afsluiting van het kwantitatieve deel van het onderzoek vervolgens markante bevindingen besproken met een aantal gesprekspartners (directeuren of onderzoeksdirecteuren). Deze gesprekken werden gehouden aan de hand van gerichte vragen rond de thema's 'vraag naar competenties', 'werving', 'samenwerking' en 'toekomstperspectief'. Er zijn gesprekken gevoerd met vier personen uit kennisinstellingen (2), grote bedrijven (I) en het MKB (I). Wanneer relevant zijn de resultaten uit de kwalitatieve gesprekken verwerkt in dit rapport, waarbij de gesprekspartners zijn geanonimiseerd.

\subsection{Life Sciences}

Bij de definitie van Life Sciences in de rest van dit rapport is aangesloten bij de ISCED classificatie (ISCDED 42). De volgende opleidingsrichtingen vallen binnen de definitie: chemie, biochemie, chemische analyse, polymeerchemie, biometrie, biotechnologie, moleculaire biologie, nanotechnologie, bioelectronica, microbiologie, bacteriologie, natuurkunde, plantkunde, materiaalkunde, biofysica, farmacologie, biomedisch, medische fysica e.d., toxicologie, voedingskunde, levensmiddelen technologie en andere disciplines. 



\section{Instroom en uitstroom}

In dit hoofdstuk wordt gekeken naar de samenstelling van het personeelsbestand van de organisaties in de Life Sciences en de veranderingen die daar in zijn opgetreden door de instroom en uitstroom van werknemers. Bij de uitstroom van werknemers wordt nader ingegaan op de redenen voor deze uitstroom.

\subsection{Samenstelling personeelsbestand}

Het overgrote deel van de werknemers in de organisaties in de Life Sciences heeft een opleiding genoten op HBO of academisch niveau. Tabel 4.I laat zien dat gemiddeld $77 \%$ van de werknemers een dergelijke opleiding heeft gehad. Opvallend is het verschil tussen het MKB enerzijds en de kennisinstellingen en grote bedrijven anderzijds: in het MKB heeft twee derde van de werknemers een $\mathrm{HBO}$ of academische opleiding afgerond, terwijl bij kennisinstellingen $86 \%$ en bij grote bedrijven $88 \%$ van de werknemers een dergelijke opleiding heeft genoten.

Tabel 4.1

Percentage hoog opgeleide werknemers per soort bedrijf

$\begin{array}{lr}\text { Kennisinstellingen } & \text { Percentage } \\ \text { Grote bedrijven } & 86 \\ \text { MKB } & 88 \\ \text { Totaal } & 66 \\ \text { *HBO of (post) academisch } & 77 \\ \text { Bron: ROA Life Sciences Survey } & \end{array}$

Maar liefst $67 \%$ van de organisaties in de Life Sciences heeft werknemers in dienst die afkomstig zijn uit het buitenland. Uit tabel 4.2 blijkt dat deze buitenlandse werknemers vaker afkomstig zijn uit een EU-land dan uit een niet EU-land. 63\% van de organisaties heeft medewerkers van binnen de EU in dienst, terwijl slechts $37 \%$ van de organisaties werknemers uit een niet EU-land in dienst heeft. Bij de organisaties die buitenlandse werknemers in dienst hebben van binnen de EU is één op de vijf werknemers uit de EU afkomstig. Bij de organisaties met werknemers van buiten de EU komt gemiddeld I op de Io werknemers uit een niet EU-land. 
Wanneer wordt gekeken naar de verschillen tussen de drie soorten organisaties dan valt op dat de grote bedrijven relatief het vaakst en het MKB relatief het minst vaak niet-Nederlandse werknemers in dienst hebben. Minder dan de helft (43\%) van het MKB heeft werknemers uit een EU-land in dienst, terwijl slechts $8 \%$ van de MKB bedrijven werknemers heeft die van buiten de EU afkomstig zijn.

\section{Tabel 4.2}

Organisaties die buitenlands personeel in dienst hebben (in procenten)

$\begin{aligned} & \text { Heeft werknemers uit een EU-land in dienst } \\ & \text { Aandeel van het } \\ & \text { werknemersbestand } \\ & \text { (indien ja) }\end{aligned}$
$\begin{aligned} & \text { Kennisinstellingen } \\ & \text { Grote bedrijven }\end{aligned}$
$\begin{aligned} & \text { MKB } \\ & \text { Totaal }\end{aligned}$
Van alle bedrijven heeft 63\% een of meerdere personen uit een EU-land in dienst.

\subsection{Instroom van personeel}

Een personeelsbestand is zelden statisch, immers werknemers komen en gaan. Deze paragraaf gaat in op de instroom van hoogopgeleid personeel. Volgens tabel 4.3 heeft drie kwart van de organisaties in de afgelopen I2 maanden te maken gehad met instroom van één of meer nieuwe hoogopgeleide werknemers. De kennisinstellingen hebben in de afgelopen I2 maanden allemaal te maken gehad met instroom van hoogopgeleid personeel en van de grote bedrijven heeft $86 \%$ personeel aangenomen in die periode. Daarentegen heeft slechts iets meer dan de helft van het MKB (56\%) te maken gehad met instroom van hoogopgeleide medewerkers.

\section{Tabel 4.3}

Instroom van hoogopgeleide werknemers in de Life Sciences in de afgelopen 12 maanden (in procenten)

$\begin{array}{lrr}\text { Soort bedrijf } & \begin{array}{r}\text { Percentage bedrijven } \\ \text { met instroom van nieuwe } \\ \text { hoogopgeleide werknemers }\end{array} & \text { Instroompercentage } \\ \text { Kennisinstellingen } & 100 & 20 \\ \text { Grote bedrijven } & 84 & 18 \\ \text { MKB } & 56 & 16 \\ \text { Totaal } & 76 & 18 \\ \text { Bron: ROA Life Sciences Survey } & & \end{array}$


Tabel 4.3 laat ook de instroompercentages zien. Het instroompercentage is het aantal ingestroomde hoogopgeleide medewerkers als percentage van het totaal aantal hoogopgeleiden in een organisatie. Voor alle organisaties die te maken hebben gehad met instroom van nieuwe hoogopgeleide medewerkers is dit percentage zeer hoog, met een gemiddelde instroom van maar liefst I $8 \%$.

Waar komen deze nieuwe hoogopgeleide medewerkers vandaan? Zoals tabel 4.4 laat zien nemen de organisaties in de Life Sciences vooral pas afgestudeerden van de universiteit aan. $6 \mathrm{I} \%$ van de organisaties zegt dat hun laatst aangestelde hoogopgeleide werknemer van de universiteit afkomstig is. Bij ongeveer 30\% van de organisaties had de laatst aangenomen hoogopgeleide werknemer een baan bij een ander organisatie. Wanneer naar de soorten organisaties wordt gekeken dan valt op dat MKB organisaties vooral hoogopgeleide werknemers aannemen die eerst bij een ander bedrijf werkzaam waren, terwijl kennisinstellingen en grote bedrijven vooral pas afgestudeerden aannemen. Een gesprekspartner uit het MKB zegt hierover: “... daarnaast krijgen we erg veel vrije sollicitaties, maar bijna geen schoolverlaters".

Tabel 4.4

Afkomst van de laatst aangestelde hoogopgeleide werknemer in de Life Sciences (in procenten)

$\begin{array}{lrrrr} & \begin{array}{r}\text { Kennis-instellingen } \\ \text { Werkzaam bij een ander bedrijf }\end{array} & \begin{array}{r}\text { Grote } \\ \text { bedrijven }\end{array} & \text { Totaal } \\ \text { Hogeschool } & 10 & 29 & 50 & 29 \\ \text { Universiteit } & 5 & 0 & 11 & 6 \\ \text { Werkloos } & 80 & 71 & 33 & 61 \\ \text { Anders } & 0 & 0 & 0 & 0 \\ \text { Totaal } & 5 & 0 & 6 & 4 \\ \text { Bron: ROA Life Sciences Survey } & 100 & 100 & 100 & 100\end{array}$

Verder is uit het onderzoek gebleken dat 50\% van de nieuw ingestroomde werknemers afkomstig zijn uit een bedrijf, hogeschool of universiteit in de regio. $26 \%$ komt van buiten de regio, maar wel uit Nederland. Zoals tabel $4.2 \mathrm{al}$ heeft laten zien hebben diverse organisaties in de Life Sciences buitenlandse medewerkers in dienst. Het blijkt dat Life Sciences organisaties nog steeds hoogopgeleide werknemers werven in het buitenland: $6 \%$ van de nieuw aangestelde hoogopgeleiden is afkomstig uit België of Duitsland en I8\% komt uit een ander land.

\subsection{Uitstroom van personeel}

Ruim 40\% van de organisaties in de Life Sciences heeft in de afgelopen I2 maanden één of meer hoogopgeleide werknemers zien vertrekken. Opvallend is dat slechts een kwart van de MKB organisaties hoogopgeleide werknemers heeft zien vertrekken, 
terwijl dit percentage bij de kennisinstellingen $55 \%$ en bij de grote bedrijven zelfs $63 \%$ is.

Analoog aan de instroompercentages in de vorige paragraaf (zie tabel 4.3) zijn in tabel 4.5 de uitstroompercentages berekend. Het uitstroompercentage is het aantal uitgestroomde hoogopgeleide medewerkers als percentage van het totaal aantal hoogopgeleiden in een organisatie. Gemiddeld is $8 \%$ van de hoogopgeleide werknemers vertrokken uit de organisaties in de Life Sciences. Bij de kennisinstellingen is het uitstroompercentage met $\mathrm{I} 3 \%$ iets hoger terwijl dit bij de grote bedrijven slechts $3 \%$ bedraagt.

\section{Tabel 4.5}

Uitstroom van hoogopgeleide werknemers in de Life Sciences in de afgelopen 12 maanden (in procenten)

\begin{tabular}{lrr} 
& $\begin{array}{r}\text { Percentage bedrijven met } \\
\text { uitstroom van hoogopgeleide } \\
\text { werknemers }\end{array}$ & Uitstroompercentage \\
\hline Kennisinstellingen & 55 & 13 \\
Grote bedrijven & 63 & 3 \\
MKB & 27 & 9 \\
Totaal & 44 & 8 \\
Bron: ROA Life Sciences Survey & &
\end{tabular}

Een vergelijking tussen de instroom- en uitstroompercentages lijkt te wijzen op een sterke toename van de werkgelegenheid in de Life Sciences. Immers, het instroompercentage bedraagt gemiddeld I8\% (zie tabel 4.3 ) terwijl het uitstroompercentage gemiddeld slechts $8 \%$ bedraagt (zie tabel 4.5 ).

\section{Tabel 4.6}

Reden van vertrek (volgens leidinggevende) voor de laatst vertrokken hoogopgeleide medewerker in de Life Sciences (in procenten)

$\begin{array}{lr} & \% \\ \text { Vrijwillig ontslag } & 54 \\ \text { Vertrokken naar andere afdeling of vestiging } & 13 \\ \text { Aflopen van tijdelijk contract } & 10 \\ \text { (Pre) pensioen } & 7 \\ \text { Gedwongen ontslag } & 3 \\ \text { (Vervolg) studie } & 3 \\ \text { Anders } & 10 \\ \text { Totaal } & 100 \\ \text { Bron: ROA Life Sciences Survey } & 100\end{array}$

Tabel 4.6 geeft een beeld van de redenen voor de uitstroom van hoogopgeleide werknemers in de Life Sciences. In iets meer dan de helft van de gevallen is de laatst 
vertrokken hoogopgeleide medewerker vrijwillig vertrokken. ${ }^{\mathrm{I}}$ Dit sluit aan bij de bevindingen van tabel 4.4 waarin gemiddeld $29 \%$ van de laatst aangenomen hoogopgeleide werknemers uit een ander bedrijf afkomstig is. Daarnaast is $13 \%$ van de vertrokken hoogopgeleide medewerkers naar een andere afdeling of vestiging binnen dezelfde organisatie gegaan. Nog eens IO\% heeft geen nieuw contract gekregen en is daarom vertrokken.

In geval van vrijwillig vertrek blijkt uit tabel 4.7 dat de vertrekkende hoogopgeleide medewerkers ergens anders een baan kunnen krijgen met betere loopbaanperspectieven $(45 \%)$ of die inhoudelijk interessanter is $(30 \%)$. Verder is in $25 \%$ van de gevallen van vrijwillig vertrek sprake van betere arbeidsvoorwaarden en nog eens $20 \%$ vertrekt vrijwillig omdat hij/zij bij een andere organisatie meer kan verdienen.

\section{Tabel 4.7}

Motief van vrijwillig vertrek (volgens leidinggevende) van de laatst vertrokken hoogopgeleide werknemer in de Life Sciences (in procenten)*

$\begin{array}{lr}\text { Kon elders een baan krijgen met betere loopbaanperspectieven } & \text { Percentage } \\ \text { Kon elders een baan krijgen die inhoudelijk interessanter was } & 45 \\ \text { Kon elders een baan krijgen met beter arbeidsvoorwaarden } & 30 \\ \text { Kon elders een baan krijgen voor een hoger salaris } & 25 \\ \text { Onenigheid op het werk } & 20 \\ \text { Te weinig mogelijkheden voor opleiding en ontwikkeling } & 15 \\ \text { Kon elders een baan krijgen met meer variatie in werkzaamheden } & 10 \\ \text { Anders } & 0 \\ \text { *Meerdere antwoorden mogelijk } & 10\end{array}$

I. Aan de organisaties die te maken hebben gehad met het vertrek van een hoogopgeleide werknemer (behalve in geval van gedwongen ontslag) is gevraagd of zij deze werknemer liever hadden willen behouden. $59 \%$ van deze organisaties had de vertrokken medewerker liever willen behouden voor de organisatie. 



\section{Knelpunten op de arbeidsmarkt}

In dit hoofdstuk komt de arbeidsmarkt voor werknemers in de Life Sciences aan bod. Als eerste wordt besproken in welke mate organisaties in de Life Sciences op dit moment problemen ervaren bij het werven van medewerkers en welke personeelstekorten er zijn. Vervolgens wordt ingegaan op de verwachte in- en uitstroom van hoogopgeleide medewerkers in de komende vijf jaar. Tot slot komen de wervingsinstrumenten aan bod die de organisaties in de Life Sciences gebruiken en hun effectiviteit.

\subsection{Knelpunten bij het zoeken naar personeel}

Op dit moment of in de afgelopen I2 maanden zijn organisaties in de Life Sciences volgens tabel 5.I vooral op zoek geweest naar nieuwe medewerkers met een $\mathrm{HBO}$ $(58 \%)$ en of een academisch opleidingsniveau (68\%). Slechts $20 \%$ van de organisaties is nu op zoek of is in de afgelopen I2 maanden op zoek geweest naar MBO'ers. Grote bedrijven en kennisinstellingen zijn relatief vaker op zoek naar academisch geschoolde medewerkers dan bedrijven uit het MKB. Hierbij zoeken kennisinstellingen relatief meer naar promovendi terwijl grote bedrijven een voorkeur hebben voor gepromoveerde werknemers.

Tabel 5.1

Percentage bedrijven dat momenteel een vacature heeft of in het afgelopen 12 maanden op zoek is geweest naar Life Sciences werknemers, naar niveau van de vacature

\begin{tabular}{lrrrrrr} 
& MBO & HBO & Academisch & \multicolumn{3}{c}{ Waarvan: } \\
& & & & Ac. master & Promovendus & Gepromoveerd \\
Kennisinstellingen & 20 & 60 & 85 & 45 & 75 & 50 \\
Grote bedrijven & 0 & 56 & 81 & 31 & 38 & 81 \\
MKB & 30 & 58 & 52 & 39 & 24 & 21 \\
Totaal & 20 & 58 & 68 & 39 & 42 & 43 \\
Bron: ROA Life Sciences Survey & & & & & &
\end{tabular}

In hoeverre ervaren organisaties problemen bij het vervullen van bovengenoemde vacatures? Uit dit onderzoek blijkt dat het vinden van geschikte medewerkers voor vacatures op $\mathrm{MBO}$ niveau geen al te grote problemen oplevert (zie tabel B.I in de bijlage). De organisaties beoordelen hun problemen met het vervullen van vaca- 
tures gemiddeld met een 2,9 op een 5-puntsschaal ( $\mathrm{I}=$ geen problemen, $5=$ erg veel problemen).

Het vinden van hoogopgeleide medewerkers levert volgens veel bedrijven iets meer problemen op: gemiddeld beoordelen de organisaties die problemen met een 3,3 op dezelfde 5-puntsschaal (zie tabel 5.2). De kennisinstellingen en grote bedrijven ervaren gemiddeld genomen iets meer problemen bij het vervullen van hun vacatures voor hoogopgeleide werknemers dan het MKB. Dit onderschat echter de problemen in het $\mathrm{MKB}$. Bij het MKB is het beeld immers veel gevarieerder: $22 \%$ van de MKB bedrijven heeft geen problemen, terwijl $17 \%$ van hen juist erg veel problemen heeft met het vervullen van vacatures op $\mathrm{HBO}$ of academisch niveau.

\footnotetext{
Een gesprekspartner uit het MKB vat het probleem als volgt samen: "Eigenlijk is het arbeidsmarktprobleem een kip-ei kwestie. Er is geen garantie op een arbeidsplaats, maar als er geen mensen zijn kan de sector niet groeien". Uit andere gesprekken blijkt dat de ervaren problemen bij werving niet zo nijpend zijn, maar dat er wel knelpunten voor de toekomst worden verwacht. Een gesprekspartner uit kennisinstellingen: "We kunnen nog steeds veel mensen krijgen". Een gesprekspartner uit een groot bedrijf zegt het volgende: "Veel mensen reageren op vacatures". Ook voor het MKB vallen de wervingsproblemen mee: "Tot nu toe geen klachten gehad om mensen te vinden". Echter, de veroudering van het personeelsbestand en de snelle groei van sommige MKB bedrijven baart zorgen: " $O P$ dit moment begint het wel lastig te worden om echte specialisten te vinden".
}

\section{Tabel $\mathbf{5 . 2}$}

In welke mate ervaart u problemen bij het vinden van hoogopgeleide werknemers in de Life Sciences, nu of in de afgelopen 12 maanden, naar soort bedrijf (in procenten)*

$\begin{array}{lrrrrrrr} & \begin{array}{r}1 \\ \text { geen }\end{array} & 2 & 3 & 4 & \begin{array}{r}5 \\ \text { erg veel } \\ \text { problemen }\end{array} \\ \text { Kennisinstellingen } & 6 & 11 & 28 & 33 & 22 & 100 & 3,6 \\ \text { Grote bedrijven } & 6 & 0 & 60 & 27 & 7 & 100 & 3,3 \\ \text { MKB } & 22 & 9 & 17 & 35 & 17 & 100 & 3,2 \\ \text { Totaal } & 13 & 7 & 32 & 32 & 16 & 100 & 3,3 \\ \text { * Schaal van 1: geen problem naar 5: erg veel problemen } \\ \text { Bron: ROA Life Sciences Survey }\end{array}$

De hier boven genoemde problemen met het vervullen van vacatures blijven niet zonder gevolgen: maar liefst twee derde van de organisaties geeft aan dat hierdoor werk blijft liggen. Bij ruim de helft van de organisaties neemt de werkdruk toe en zijn er minder mogelijkheden om te innoveren. De kennisinstellingen hebben van dat laatste overigens relatief minder last dan de grote bedrijven en het MKB (zie tabel B.2 in de bijlage). 


\subsection{Kwantitatief en kwalitatief tekort}

De wervingsproblemen die besproken zijn in de vorige paragraaf duiden op mogelijke personeelstekorten bij de organisaties in de Life Sciences. Bij een personeelstekort kan het gaan om een kwantitatief tekort of een kwalitatief tekort of beide. Bij een kwantitatief tekort is er onvoldoende aanbod van medewerkers, terwijl er bij een kwalitatief tekort wel aanbod is, maar dit aanbod niet aansluit op de gevraagde kwalificaties.

De meeste organisaties hebben nauwelijks een tekort aan werknemers op MBO niveau (zie tabel B.3 in de bijlage). Dit komt overeen met de relatief lage vraag naar MBO'ers (zie tabel 5.I) en de geringere wervingsproblemen bij het zoeken naar medewerkers voor functies op $\mathrm{MBO}$ niveau die in de vorige paragraaf zijn besproken. Een tekort aan HBO'ers komt vaker voor: iets meer dan de helft van de organisaties heeft een tekort aan werknemers op HBO niveau (zie tabel 5.3). Deze tekorten hebben soms ook een kwalitatieve component. De kennisinstellingen en grote bedrijven ervaren vaker een tekort aan HBO'ers dan het MKB.

Tabel 5.3

Kwalitatief of kwantitatief tekort aan werknemers in de Life Sciences op HBO niveau, naar soort bedrijf (in procenten)

$\begin{array}{lrrrr} & \text { Kennisinstellingen } & \text { Grote bedrijven } & \text { MKB } & \text { Totaal } \\ \text { Nee } & 30 & 31 & 58 & 43 \\ \text { Ja, een kwalitatief tekort } & 15 & 25 & 9 & 15 \\ \text { Ja, een kwantitatief tekort } & 30 & 13 & 27 & 25 \\ \text { Ja, zowel een kwalitatief als een kwantitatief } & 25 & 31 & 6 & 17 \\ \text { tekort } & & & & \\ \text { Totaal } & 100 & 100 & 100 & 100 \\ \text { Bron: ROA Life Sciences Survey } & & & & \end{array}$

Tabel 5.4 laat een beeld zien dat vergelijkbaar is met het beeld van tabel 5.3: iets meer dan de helft van de organisaties heeft een tekort aan werknemers op academisch niveau waarbij het doorgaans om een kwantitatief tekort gaat met een kwalitatieve component. Ook ervaren de kennisinstellingen en grote bedrijven relatief vaker een tekort aan academisch geschoolde werknemers dan de bedrijven uit het MKB.

Tabel 5.4

Kwalitatief of kwantitatief tekort aan werknemers in de Life Sciences op academisch niveau, naar soort bedrijf (in procenten)

$\begin{array}{lrrrr} & \text { Kennisinstellingen } & \text { Grote bedrijven } & \text { MKB } & \text { Totaal } \\ \text { Nee } & 25 & 38 & 64 & 46 \\ \text { Ja, een kwalitatief tekort } & 15 & 19 & 12 & 15 \\ \text { Ja, een kwantitatief tekort } & 25 & 6 & 15 & 16 \\ \text { Ja, zowel een kwalitatief als een kwantitatief } & 35 & 37 & 9 & 23 \\ \text { tekort } & & & & \\ \text { Totaal } & 100 & 100 & 100 & 100 \\ \text { Bron: ROA Life Sciences Survey } & & & & \end{array}$




\subsection{Verwachte uitstroom en instroom in de komende 5 jaar}

\section{Uitstroom in de komende 5 jaar}

Hoe denken de organisaties in de Life Sciences over de veranderingen die de komende 5 jaar in hun personeelsbestand gaan plaatsvinden? Tabel 5.5 laat zien dat twee derde van de organisaties verwacht dat één of meer hoogopgeleide werknemers in de komende

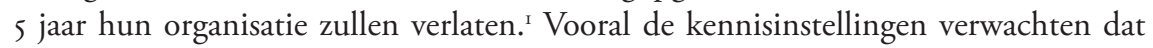
zij met uitstroom van hoogopgeleiden te maken zullen krijgen (79\%). Bij de grote bedrijven ligt dit percentage iets lager (68\%) en van de MKB bedrijven denkt 'slechts' $58 \%$ dat zij hoogopgeleide werknemers zullen kwijtraken in de nabije toekomst. Vermoedelijk heeft de verwachte uitstroom van hoogopgeleiden in de kennisinstellingen te maken met de uitstroom van aio's en postdocs. Deze uitstroom biedt vervolgens mogelijkheden voor grote bedrijven en MKB in de regio om goed gekwalificeerd personeel te werven.

Tabel 5.5 laat zien dat de verwachte uitstroom erg hoog is. De Life Sciences organisaties verwachten dat gemiddeld een kwart van de hoogopgeleide medewerkers zal uitstromen in de komende 5 jaar. De kennisinstellingen verwachten maar liefst 40\% van hun hoogopgeleiden te zien vertrekken in die periode, terwijl het MKB een personeelsverlies verwacht van I7\% van hun hoogopgeleiden.

Een verklaring voor de hoge uitstroom van hoogopgeleiden bij de kennisinstellingen ligt mogelijk in het gebruik van tijdelijke contracten (van vooral aio's), die door kennisinstellingen veel meer worden gebruikt dan door grote bedrijven en het MKB. Ook de toegenomen internationale dynamiek in de academische wereld op het gebied van de Life Sciences zou kunnen verklaren waarom juist kennisinstellingen uitstroom van hoogopgeleiden verwachten.

Tabel 5.5

Verwachte uitstroom vaan hoogopgeleide werknemers in de Life Sciences in de komende 5 jaar, naar soort bedrijf (in procenten)

$\begin{array}{lcc} & \begin{array}{r}\text { Percentage organisaties dat uitstroom van } \\ \text { hoogopgeleide werknemers verwacht }\end{array} & \text { Uitstroompercentage* } \\ \text { Kennisinstellingen } & 79 & 40 \\ \text { Grote bedrijven } & 68 & 28 \\ \text { MKB } & 58 & 17 \\ \text { Totaal } & 66 & 27 \\ \text { *Totaal uitstroom van hoogopgeleiden als percentage van het aantal hoogopgeleiden } & \\ \text { Bron: ROA Life Sciences Survey } & \end{array}$

I. In de enquête is niet gevraagd naar de verwachte uitstroom van werknemers op MBO niveau. 
$65 \%$ van de organisaties in de Life Sciences denkt dat hun behoefte aan werknemers op MBO niveau gelijk blijft in de komende 5 jaar (zie tabel 5.6). $28 \%$ verwacht een toename van de behoefte aan MBO'ers. Deze toename in de behoefte aan MBO'ers doet zich vooral voor bij de kennisinstellingen en het MKB, maar nauwelijks bij de grote bedrijven. Een kwart van de grote bedrijven verwacht juist een afname in de vraag naar MBO'ers.

\section{Tabel 5.6}

Ontwikkeling behoefte aan werknemers in de Life Sciences op MBO niveau (in procenten)

$\begin{array}{lrrrr} & \text { Afnemen } & \text { Gelijk blijven } & \text { Toenemen } & \text { Totaal } \\ \text { Kennisinstellingen } & 0 & 63 & 37 & 100 \\ \text { Grote bedrijven } & 27 & 67 & 6 & 100 \\ \text { MKB } & 0 & 66 & 34 & 100 \\ \text { Totaal } & 7 & 65 & 28 & 100 \\ \text { Bron: ROA Life Sciences Survey } & & & \end{array}$

De behoefte aan hoogopgeleide werknemers in de komende 5 jaar zal volgens tabel 5.7 voor ongeveer de helft van de organisaties toenemen. Iets minder dan de helft van de organisaties geeft aan dat de behoefte gelijk zal blijven. Slechts een zeer klein percentage verwacht dat de behoefte zal afnemen.

\section{Tabel 5.7}

Ontwikkeling behoefte aan hoogopgeleide werknemers in de Life Sciences (in procenten)

\begin{tabular}{|c|c|c|c|c|c|}
\hline & & Afnemen & Gelijk blijven & Toenemen & Totaal \\
\hline \multirow[t]{4}{*}{ HBO } & Kennisinstellingen & 0 & 44 & 56 & 100 \\
\hline & Grote bedrijven & 12 & 38 & 50 & 100 \\
\hline & MKB & 0 & 45 & 55 & 100 \\
\hline & Totaal & 3 & 43 & 54 & 100 \\
\hline \multirow[t]{4}{*}{ Masters degree } & Kennisinstellingen & 0 & 56 & 44 & 100 \\
\hline & Grote bedrijven & 14 & 43 & 43 & 100 \\
\hline & MKB & 0 & 50 & 50 & 100 \\
\hline & Totaal & 3 & 50 & 47 & 100 \\
\hline \multirow[t]{4}{*}{ Promovendus } & Kennisinstellingen & 0 & 12 & 88 & 100 \\
\hline & Grote bedrijven & 13 & 40 & 47 & 100 \\
\hline & MKB & 0 & 73 & 27 & 100 \\
\hline & Totaal & 3 & 47 & 50 & 100 \\
\hline \multirow[t]{4}{*}{ Gepromoveerd } & Kennisinstellingen & 0 & 12 & 88 & 100 \\
\hline & Grote bedrijven & 12 & 38 & 50 & 100 \\
\hline & MKB & 4 & 63 & 33 & 100 \\
\hline & Totaal & 5 & 42 & 53 & 100 \\
\hline
\end{tabular}


De behoefte aan werknemers met een HBO opleiding of een Masters degree in de komende 5 jaar verschilt nauwelijks tussen de drie soorten organisaties. Daarentegen geven kennisinstellingen en grote bedrijven vaker dan het MKB aan dat zij een toenemende behoefte hebben aan promovendi en gepromoveerde werknemers.

\subsection{Gebruikte wervingsinstrumenten}

Uit de vorige paragraaf is gebleken dat de behoefte aan vooral hoogopgeleide medewerkers de komende jaren zal toenemen. Deze werknemers zullen dus geworven moeten worden. Welke wervingsinstrumenten gebruiken de organisaties in de Life Sciences en hoe effectief zijn deze instrumenten? ${ }^{2}$

De meest favoriete wervingsinstrumenten zijn het eigen netwerk, universiteiten en hoge scholen (stages), internet en het eigen personeel (zie figuur 5.I). Van de meer traditionele wervingsinstrumenten zoals wervingsadvertenties, uitzendbureaus en commerciële wervingsbureaus maken de organisaties in de Life Sciences mondjesmaat gebruik.

De frequentie van het gebruik van de verschillende wervingsinstrumenten verschilt niet veel tussen de drie soorten organisaties (zie tabel B.4 in de bijlage). Grote bedrijven geven relatief het vaakst aan instrumenten als wervingsadvertenties, uitzendbureaus en commerciële wervingsbureaus, en internet te gebruiken. Dit kan te maken hebben met de grotere beschikbaarheid van wervingsbudgetten in grote bedrijven die het mogelijk maken om van deze (kostbare) instrumenten gebruik te maken (een gesprekspartner uit het MKB: "Werving is erg duur"). Ook ontvangen grote bedrijven relatief vaker open sollicitaties wat kan samenhangen met de grotere (naams) bekendheid van grote bedrijven ten opzichte van kennisinstellingen en het MKB. De kennisinstellingen maken relatief het meest gebruik van hun eigen netwerk en personeel om nieuwe medewerkers te werven. Het MKB werft minder vaak in het buitenland dan grote bedrijven en kennisinstellingen. Het lijkt er dus op dat werven in het buitenland voor het MKB nog betrekkelijk onbekende terrein is. De wervingsinstrumenten die relatief het meest gebruikt worden, worden doorgaans als effectief beoordeeld. Het eigen netwerk en personeel worden als meest effectieve wervingsinstrumenten gezien (zie figuur B.I en tabel B.5 in de bijlage).

\footnotetext{
Wat betreft de werving werkt het eigen netwerk volgens de gesprekspartners het beste. "Ofje mensen kan vinden hangt erg veel van connecties af, mensen komen mee in de slipstream van anderen", zo zegt een gesprekspartner uit een kennisinstelling. Er zijn echter ook aanwijzingen dat het eigen netwerk niet altijd ten volle benut wordt. Dit is met name in grote organisaties het geval.
}

2. In het tweede deel van dit rapport gaan wij dieper in op de werving van kenniswerkers. 
Traditionele wervingsinstrumenten lijken goed te werken voor grote bedrijven: "Veel mensen reageren op de vacatures op de website, dat is een goed medium. We krijgen ook veel open sollicitaties. Als het moeilijker wordt om iemand te vinden worden advertenties gezet in bv Intermediair, vakbladen en 'beta-banen'. Dit is vooral voor starters. Voor de hogere functies worden headhunters ingeschakeld."

\section{Figuur 5.1}

Gebruik van wervingsinstrumenten voor het werven van hoogopgeleide werknemers in de Life Sciences (in procenten)

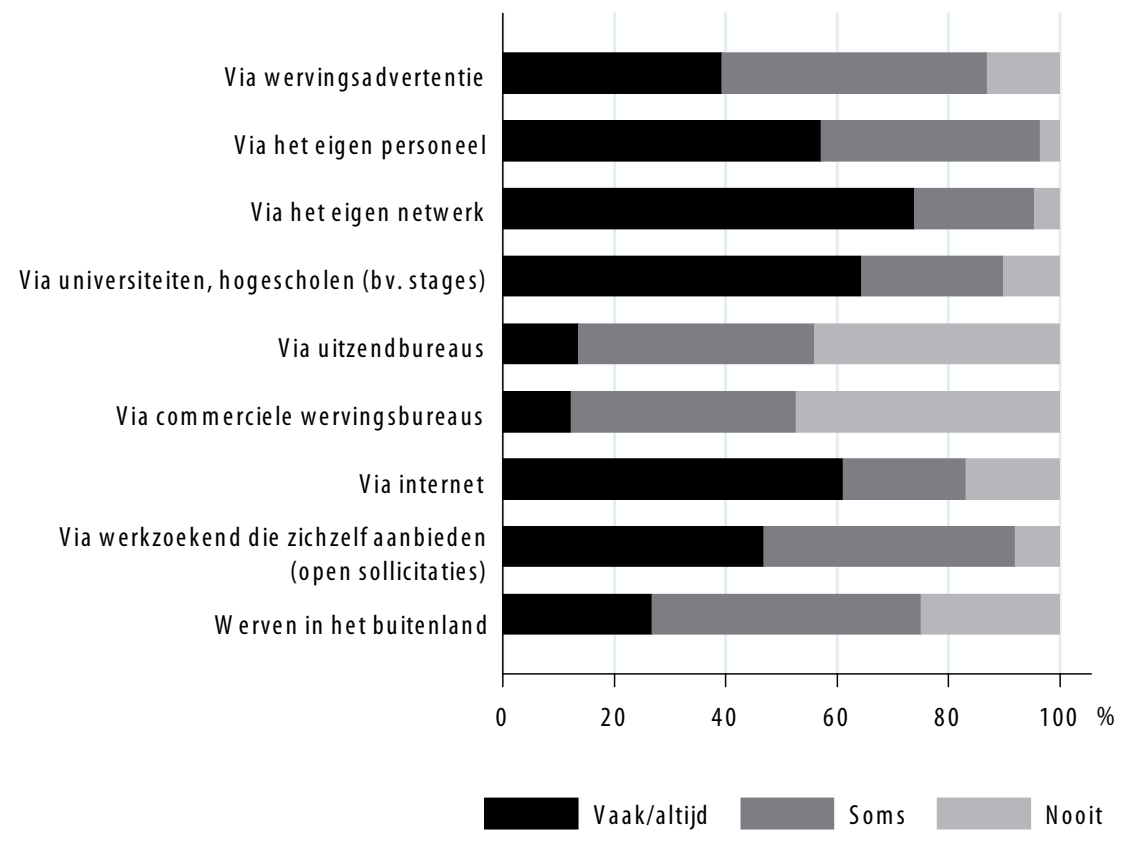

Bron: ROA Life Sciences Survey

Hoewel organisaties in de Life Sciences op dit moment nog niet zo vaak werven in het buitenland is de bereid hiertoe wel degelijk aanwezig. Figuur 5.2 laat zien dat vooral België, Duitsland en de Verenigde Staten geliefde landen zijn om nieuwe medewerkers te werven. Oost-Europa (inclusief de voormalige Oostbloklanden) en Azië lijken minder populair te zijn. 


\section{Figuur 5.2}

Bereidheid om hoogopgeleide werknemers in de Life Sciences in het buitenland te werven (percentage)

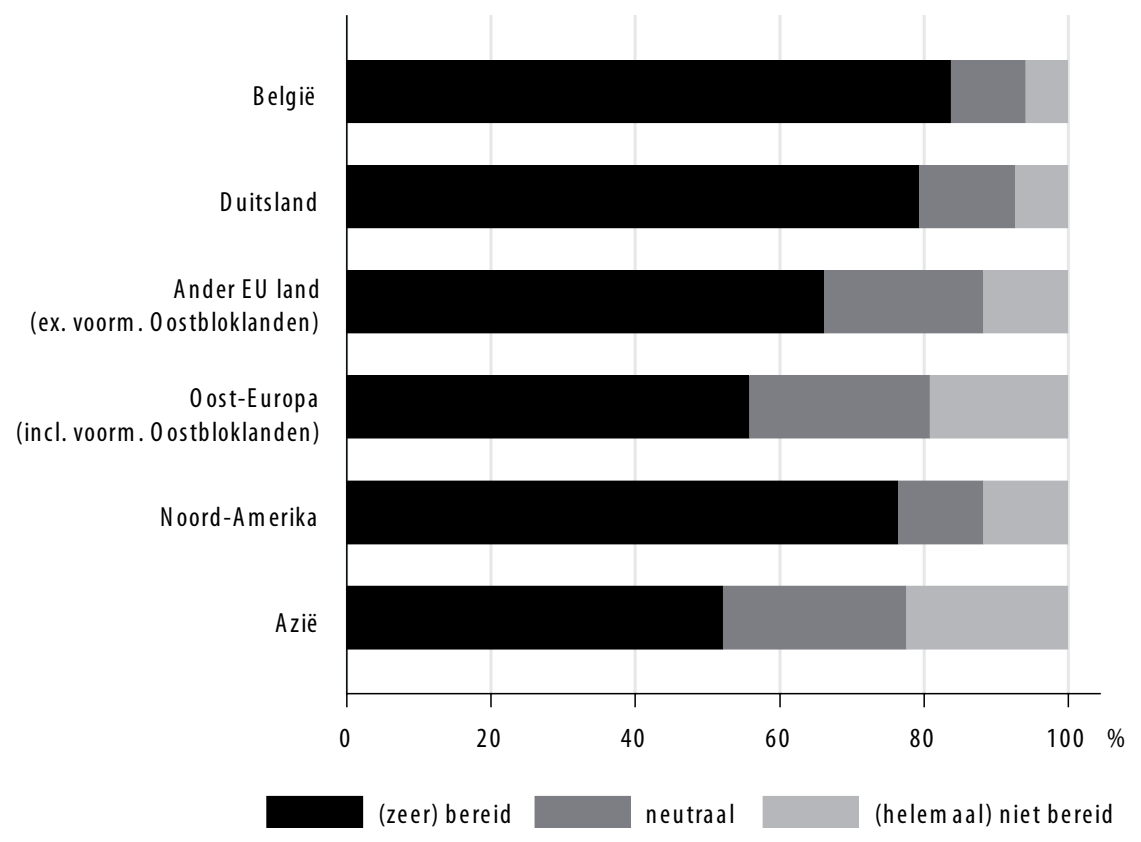

Bron: ROA Life Sciences Survey

Wanneer de bereidheid naar het werven in de verschillende landen bekeken wordt, valt op dat het MKB in alle landen een lagere bereidheid tot werven laat zien dan de grote bedrijven en de kennisinstellingen (zie tabel 5.8). Dit komt overigens overeen met de lagere frequentie van het gebruik van het wervingsinstrument 'Werven in het buitenland' door het MKB zoals besproken bij figuur 5.I. De bereidheid om in het buitenland te werven is bij de grote bedrijven relatief het meest aanwezig: grote bedrijven zijn vooral meer dan de kennisinstellingen bereid om in Oost-Europa (inclusief de voormalige Oostbloklanden) en Azië te werven.

Uit de kwalitatieve gesprekken blijkt dat werving in het buitenland niet systematisch plaatsvindt. Een gesprekspartner uit een groot bedrijf verwacht wel dat het aandeel buitenlandse werknemers in de toekomst zal toenemen. Een kennisinstelling zegt hierover: "Werving over meer landen gebeurt niet systematisch"; "Vergeleken met de Randstad hebben we relatief gezien niet veel mensen uit het buitenland". Een andere kennisinstelling geeft aan: "We hebben tot voor kort erg regionaal geworven, maar nu ook wereldwijd. We hebben nog geen zicht op het effect daarvan". Een gesprekspartner bij het MKB merkt het volgende op "Met in het buitenland werven zijn wij niet actief" om er aan toe te voegen "mensen van ver zijn altijd duurder". Gesprekspartners lijken overigens niet zo happig op werknemers uit Azië. Culturele verschillen, verschillen in competenties op 
het gebied van communicatie lijken daar aan ten grondslag te liggen. Ook kennisinstellingen zien "Azië niet zozeer als wervingsgebied". Waar wel potentieel in wordt gezien is het aantrekken van Aziatische studenten die hier worden gevormd.

Tabel 5.8

Bereidheid om hoogopgeleide werknemers in de Life Sciences in het buitenland te werven, naar soort organisatie (gemiddelde score)*

$\begin{array}{lrrr} & \text { Kennis-instellingen } & \text { Grote bedrijven } & \text { MKB } \\ \text { België } & 4.7 & 4.8 & 4.0 \\ \text { Duitsland } & 4.6 & 4.8 & 3.7 \\ \text { Een ander EU land (excl. voormalige 0ostbloklanden) } & 4.4 & 4.6 & 3.2 \\ \text { Oost-Europa (incl. voormalige 0ostbloklanden) } & 3.8 & 4.3 & 3.0 \\ \text { Noord-Amerika } & 4.6 & 4.6 & 3.3 \\ \text { Azië } & 3.6 & 4.1 & 3.0\end{array}$

* Gemiddelde op schaal van 1: "helemaal niet bereid" tot 5 "zeer bereid" Bron: ROA Life Sciences Survey 



\section{Vereiste competenties}

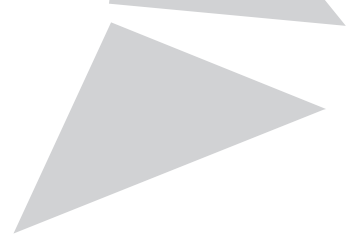

Hoe ziet de ideale hoogopgeleide werknemer voor de organisaties in de Life Sciences eruit nu en in de toekomst? Welke opleidingsachtergrond moet hij of zij hebben en welke competenties moet hij of zij bezitten? Deze vragen worden beantwoord in de eerste twee paragrafen van dit hoofdstuk. Vervolgens wordt ingegaan op de cursussen en trainingen die de hoogopgeleiden in de Life Sciences volgen en in de laatste paragraaf wordt besproken op welke manieren deze medewerkers hun competenties verwerven.

\subsection{Disciplines nu en in de toekomst}

\section{Huidige behoefte naar opleidingsachtergrond}

Aan de organisaties in de Life Sciences is gevraagd aan welke discipline (of opleidingsachtergrond) van de hoogopgeleide werknemers zij de meeste behoefte hebben. Uit een lijst van 17 disciplines konden organisaties aangeven aan welke 5 disciplines zij vooral behoefte hebben om daarbinnen vervolgens aan te geven aan welke disciplines zij het meest behoefte hebben. Dit geeft inzicht in zowel de vraag naar een bepaalde opleidingsachtergrond als het belang van de betreffende opleiding.

Figuur 6.I laat zien dat de disciplines biomedisch, biotechnologie, moleculaire biologie en biochemie relatief het vaakst genoemd worden. Deze disciplines worden ook als zeer belangrijk ervaren: gemiddeld scoren deze disciplines bijna een 4 op een 5-puntsschaal ( $\mathrm{I}=$ minst belangrijke discipline, $5=$ belangrijkste discipline). Sommige disciplines worden als zeer belangrijk gezien met een gemiddelde score tussen 3 en 4 (op dezelfde 5 puntsschaal) maar worden door veel minder bedrijven genoemd. Dit zijn de disciplines chemie, polymeerchemie, biometrie en natuur- en plantkunde waar blijkbaar een zeer specifieke vraag naar is bij enkele organisaties in de Life Sciences.

Bij de analyse van de resultaten naar soort bedrijf valt op dat het MKB de categorie anders veel vaker noemt dan de kennisinstellingen en grote bedrijven: $35 \%$ van het MKB noemt de categorie anders tegenover I3\% van de kennisinstellingen en II\% van de grote bedrijven. Ook beoordeelt het MKB het belang van de categorie anders met maar liefst een 4,5 (zie tabel B.6 in de bijlage). Het lijkt er op dat de vraag naar disciplines van hoogopgeleide medewerkers bij het MKB gedifferentieerder is dan bij de 
andere organisaties in de Life Sciences. Dit hangt waarschijnlijk samen met de grotere diversiteit in de activiteiten binnen de groep van MKB bedrijven.

\begin{abstract}
Deze diversiteit wordt ook omarmd door kennisinstellingen: "Multidisciplinair is beter dan richten op individuele disciplines, multidisciplinair leidt tot betere producten"; "Als mensen opgegroeid zijn in een bepaalde discipline is er veel onzekerheid als ze iets anders moeten doen".
\end{abstract}

\title{
Figuur 6.1
}

Disciplines van hoogopgeleide werknemers in de Life Sciences die momenteel het meest relevant zijn voor de organisaties (percentage genoemd en cijfer)*

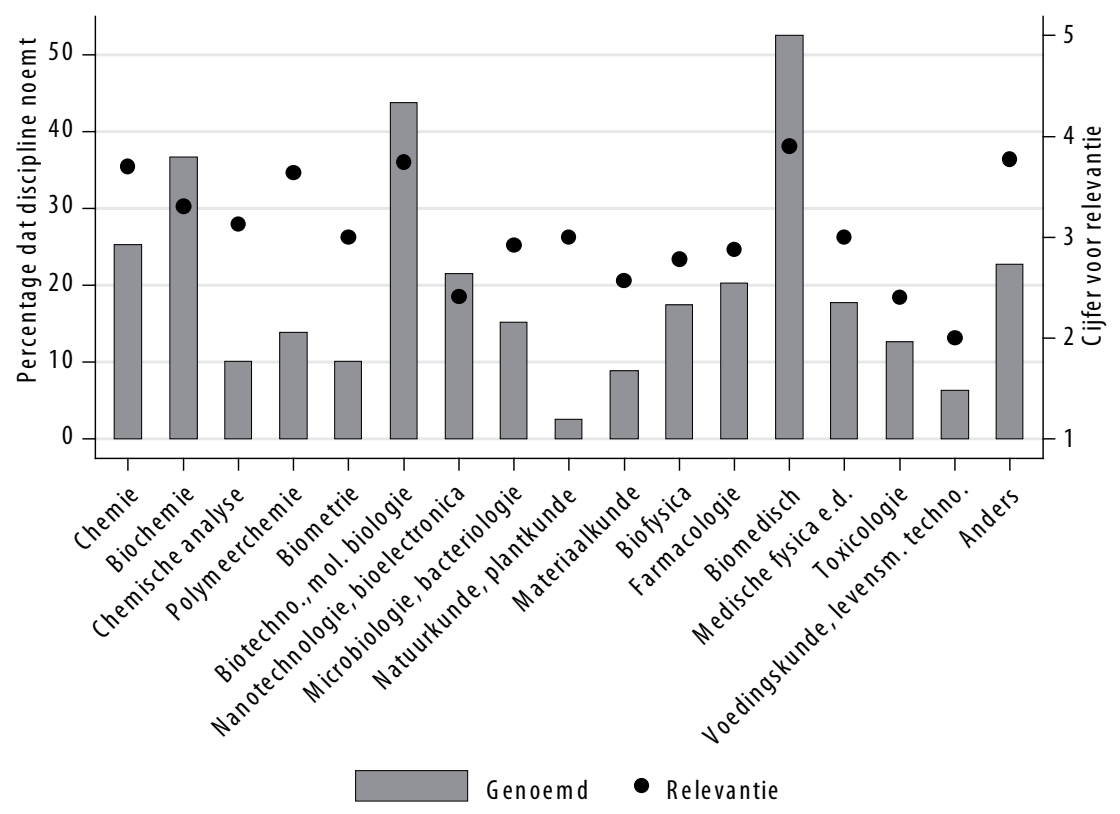

* Percentage bedrijven dat discipline noemt (maximaal 5) en het gemiddelde cijfer voor de relevantie van het vakgebied ( $5=$ discipline die best aansluit bij de behoefte, $4=$ discipline met de een na beste aansluiting,...) Bron: ROA Life Sciences Survey

\section{Behoefte naar opleidingsachtergrond in de komende 5 jaar}

Figuur 6.2 laat zien dat de toekomstige behoefte aan bepaalde disciplines (of opleidingsachtergronden) vrijwel gelijk is aan de huidige behoefte. Ook de komende 5 jaar hebben de organisaties in de Life Sciences de meeste behoefte aan hoogopgeleide werknemers uit de disciplines biomedisch, biotechnologie, moleculaire biologie en biochemie. Het MKB blijft ook in de toekomst behoefte houden aan een grotere diversiteit aan disciplines dan de kennisinstellingen en grote bedrijven: $33 \%$ van het $\mathrm{MKB}$ vulde de categorie Anders in, tegenover ruim IO\% van de kennisinstellingen en 
grote bedrijven. Aan de andere kant geven de MKB bedrijven relatief het vaakst aan (II\%) nog geen zicht te hebben op de toekomstige behoefte aan bepaalde disciplines (zie tabel B.7 in de bijlage)

\section{Figuur 6.2}

Disciplines van hoogopgeleide werknemers in de Life Sciences waar in de komende 5 jaar de meeste behoefte aan zal zijn (percentage organisaties dat discipline noemt)*

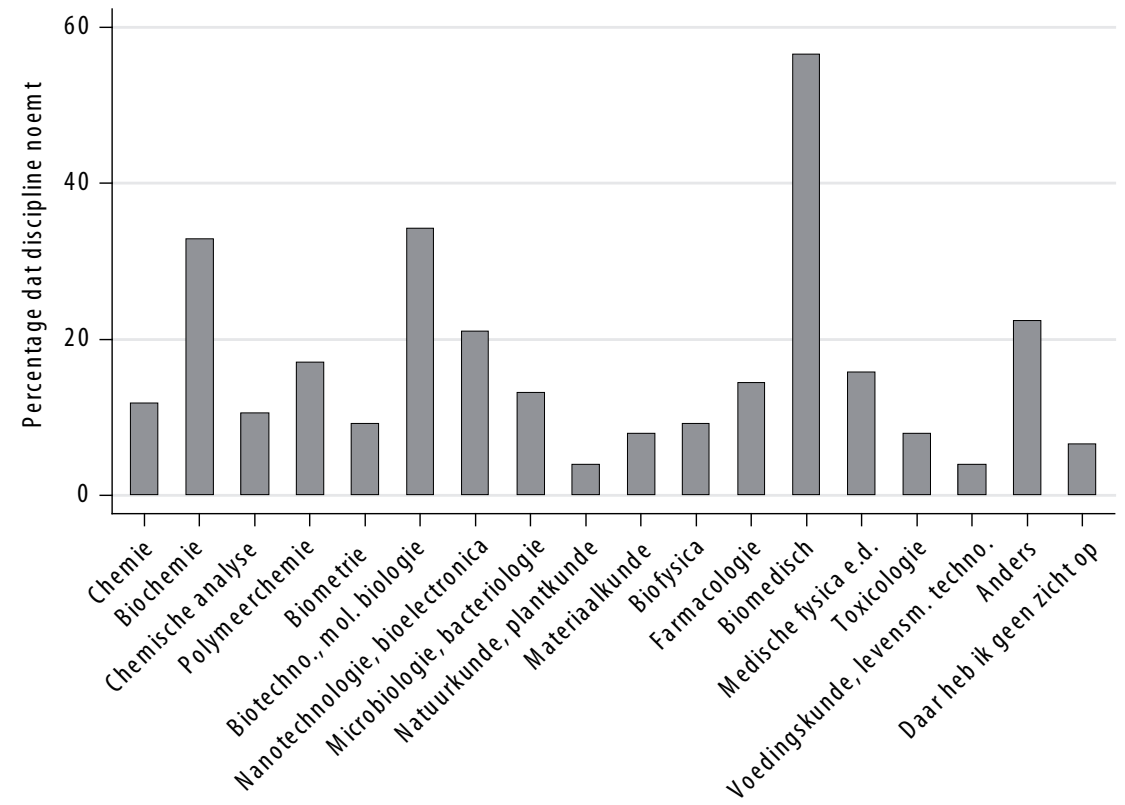

* Maximaal 5 disciplines konden worden genoemd Bron: ROA Life Sciences Survey

De organisaties in de Life Sciences verwachten dat zij in de komende 5 jaar de minste behoefte zullen hebben aan hoogopgeleide werknemers met een opleiding uit de richtingen natuurkunde, plantkunde, polymeerchemie, materiaalkunde, voedingskunde, levensmiddelentechnologie en biometrie (zie figuur 6.3 en tabel B.8 in de bijlage). Echter, voor sommige bedrijven zijn deze specialisaties erg belangrijk. Zonder deze specialisaties kunnen zij niet produceren. Het lijkt dus van belang dat het hoger onderwijs een goede mix van disciplines probeert te realiseren. 


\section{Figuur 6.3}

Disciplines van hoogopgeleide werknemers in de Life Sciences waar in de komende 5 jaar de minste behoefte aan zal zijn (percentage organisaties dat discipline noemt)*

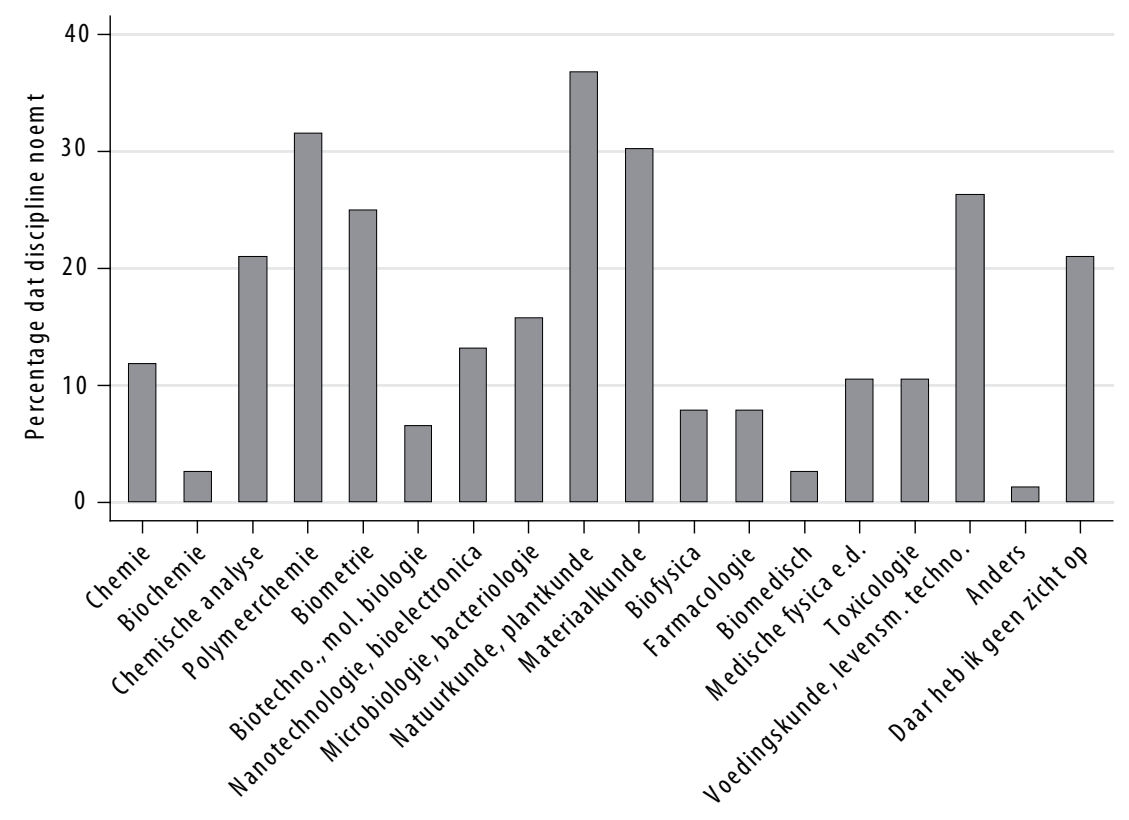

* Maximaal 5 disciplines konden worden genoemd Bron: ROA Life Sciences Survey

\subsection{Competenties nu en in de toekomst}

\section{Competenties van de huidige medewerkers}

Naast een opleiding uit een bepaalde richting is het ook van belang dat hoogopgeleide werknemers bepaalde competenties bezitten. Tabel 6.I geeft een overzicht van het niveau van de competenties die de huidige hoogopgeleide werknemers in de Life Sciences organisaties op dit moment bezitten. Gemiddeld genomen geven organisaties aan dat hun hoogopgeleide werknemers een goed vermogen hebben om te leren. Gemiddeld scoren de hoogopgeleiden hierop een 4, I gemeten op een 5-puntsschaal (I = ruim onvoldoende, 5 = uitstekend). De hoogopgeleide werknemers werkzaam in de kennisinstellingen beschikken daarnaast over een hoog niveau op de gebieden kennis kunnen delen $(4, \mathrm{I})$, fundamenteel onderzoek doen, zelfstandig werken, probleemoplossend vermogen hebben en ambitieus zijn $(3,8)$. Bij de grote bedrijven beschikken de hoogopgeleide werknemers vooral over de competenties zelfstandig werken $(4,2)$ en zijn zij beter in het doen van toegepast onderzoek $(4,4)$ dan fundamenteel onder- 
zoek $(3,9)$. In het MKB liggen de competenties van de hoogopgeleiden vooral op de gebieden van werken in teamverband $(4,2)$ en het oplossen van problemen $(4,0)$.

\section{Tabel 6.1}

Competentieniveau van hoogopgeleide werknemers in de Life Sciences op dit moment (gemiddelde score)*

\begin{tabular}{|c|c|c|c|c|}
\hline & $\begin{array}{l}\text { Kennis- } \\
\text { instellingen }\end{array}$ & Grote bedrijven & MKB & Totaal \\
\hline Fundamenteel onderzoek kunnen doen & 3,8 & 3,9 & 3,2 & 3,5 \\
\hline Toegepast onderzoek kunnen doen & 3,7 & 4,4 & 3,7 & 3,8 \\
\hline Ondernemend & 2,9 & 3,1 & 3,6 & 3,3 \\
\hline Risico's durven nemen & 3,1 & 3,1 & 3,6 & 3,3 \\
\hline Commercieel inzicht & 2,3 & 2,8 & 3,2 & 2,8 \\
\hline Flexibel, omgaan met veranderingen & 3,2 & 3,5 & 3,6 & 3,5 \\
\hline Communicatief & 3,6 & 3,6 & 3,7 & 3,6 \\
\hline Kennis kunnen delen & 4,1 & 3,8 & 3,7 & 3,8 \\
\hline Vermogen om te leren & 4,1 & 4,2 & 4,0 & 4,1 \\
\hline Organiseren en managen van projecten & 3,1 & 3,4 & 3,8 & 3,5 \\
\hline Leidinggeven & 2,8 & 3,1 & 3,5 & 3,2 \\
\hline Omgaan met andere disciplines & 3,2 & 3,6 & 3,6 & 3,5 \\
\hline Ambitieus & 3,8 & 3,6 & 3,8 & 3,8 \\
\hline Assertief & 3,6 & 3,5 & 3,7 & 3,6 \\
\hline Creatief, innovatief & 3,8 & 3,8 & 3,9 & 3,8 \\
\hline Werken in teamverband & 3,7 & 3,9 & 4,2 & 4,0 \\
\hline Zelfstandig werken & 3,8 & 4,2 & 3,9 & 3,9 \\
\hline Probleemoplossend vermogen & $\begin{array}{l}3,8 \\
\text { 2unitst }\end{array}$ & 3,9 & 4,0 & 3,9 \\
\hline
\end{tabular}

Uit de gesprekken blijkt dat organisaties op zoek zijn naar een duizendpoot (“high potential'), die alle competenties bezit. Tegelijkertijd beseffen ze dat deze duizendpoot niet bestaat: "De droomstudent bestaat niet", zegt een groot bedrijf; “Die zijn er niet veel”, zegt het MKB. Het aantrekken van academische toppers heeft volgens kennisinstellingen voordelen in termen van "uitbreiding van het netwerk", maar volgens grote bedrijven ook risico's "Ultieme toppers die gaan uiteindelijk weer weg".

\section{Competenties in de toekomst}

De behoefte aan competenties van hoogopgeleide medewerkers in de komende 5 jaar laat een aantal opmerkelijke veranderingen zien ten opzichte van de competenties die de huidige hoogopgeleiden bezitten. Tabel 6.2 laat zien dat de kennisinstellingen in de toekomst meer behoefte zullen hebben aan hoogopgeleiden die goed zijn in projectorganisatie en projectmanagement, toegepast onderzoek kunnen doen en creatief en innovatief zijn. Ruim $40 \%$ van de kennisinstellingen denkt dat zij in de komende 5 
jaar meer behoefte aan deze competenties zal hebben. Opvallend is dat een kwart van de kennisinstellingen in de toekomst meer behoefte zal hebben aan hoogopgeleide medewerkers die fundamenteel onderzoek kunnen doen, terwijl een groep van gelijke omvang aangeeft juist minder behoefte te zullen hebben aan hoogopgeleiden met deze competentie.

Op de vraag hoe de behoefte aan generieke competenties zich verhoudt tot inhoudelijke vakkennis, geeft een gesprekspartner uit een kennisinstelling aan dat men eerder voor de inhoudsdeskundige dan voor degene die vooral generieke competenties heeft zou kiezen: "Ik vind de inhoudelijke bijdrage belangrijker"; "Ik heb liever een paar Willie Wortels die kwaliteit leveren"; "We zoeken mensen die niet te braaf zijn, die kennis willen verspreiden en die nieuwe kennis willen genereren, mensen die buiten de gebaande paden durven te gaan". Het vervolgt met: "Mensen moeten echter wel in staat zijn om goed uit te kunnen leggen waar ze mee bezig zijn"; "De echte succesverhalen zijn goede ideeën die verkoopbaar gemaakt kunnen worden; zo'n Willie Wortel moet het wel kunnen verkopen. Als iemand dat niet kan kun je ook een tandem maken, dan koppel je daar iemand aan die dat wel kan".

Hoewel een andere gesprekspartner uit een kennisinstelling beaamt dat vakinhoudelijke kennis en wetenschappelijk onderzoek voorop staan, benadrukt hij dat onderwijs- en managementkwaliteiten belangrijk zijn: "Mensen moeten dat [de rol in onderwijs] dus ook zien, dat het niet alleen om onderzoek gaat"; "Iemand die niet kan leidinggeven op een serieuze plaats, dat nekt je toch"; "In hoeverre is iemand in staat een aio binnen relatief korte tijd klaar te laten zijn, die moet dan managementkwaliteiten hebben". Bovendien is ondernemerschap van belang: "We willen dat onderzoekers ondernemend zijn. Velen willen ook de wereld in".

Een groot bedrijf geeft aan behoefte te hebben aan fundamenteel onderzoekers (hoewel aandeel toegepast onderzoek wel meer is dan op de universiteit). "Daarnaast zoeken we naar mensen met managementpotentieel'. De vraag is of het wel duidelijk is wat die "high potential" precies inhoudt. Als ze een inhoudelijk deskundige zoeken en deze niet kunnen vinden, dan zoekt het grote bedrijf verder. Wanneer het de inhoudelijke topper aan generieke competenties ontbreekt, dan wordt een tijdelijk contract aangeboden in combinatie met training.

Het MKB stelt niet alleen behoefte te hebben aan "knappe koppen", maar ook aan "pragmatisch ingestelde werknemers" met goed "probleemoplossend vermogen", mensen die "een idee goed kunnen vertalen naar een uitvoerbaar project". Een probleem volgens het MKB is dat creatieve en ondernemende werknemers "moeilijk zijn te vinden en te houden".

Ruim 40\% van de grote bedrijven verwacht in de toekomst meer behoefte te hebben aan hoogopgeleiden die in staat zijn om toegepast onderzoek te doen, die ondernemend zijn en die flexibel genoeg zijn om met veranderingen te kunnen omgaan. Bij de MKB bedrijven verwacht men meer behoefte te krijgen aan medewerkers die bedreven zijn in het organiseren en managen van projecten, die commercieel inzicht 
hebben, ondernemend zijn en toegepast onderzoek kunnen doen. Zowel de grote bedrijven als het MKB verwachten dat zij minder behoefte zullen hebben aan hoogopgeleiden die fundamenteel onderzoek kunnen doen. Daarnaast heeft het MKB de komende 5 jaar minder behoefte aan assertieve hoogopgeleide werknemers.

Tabel 6.2

Percentage arbeidorganisaties dat aangeeft dat competenties van hoogopgeleide werknemers in de Life Sciences minder of meer belangrijk zullen worden in de komende 5 jaar (in procenten)*

\begin{tabular}{lrrrrrrrr} 
& \multicolumn{1}{c}{ Kennisinstellingen } & Grote bedrijven & & MKB & Totaal \\
& Minder & Meer & Minder & Meer & Minder & Meer & Minder & Meer \\
\hline Fundamenteel onderzoek kunnen doen & 26 & 26 & 29 & 12 & 31 & 22 & 29 & 21 \\
Toegepast onderzoek kunnen doen & 0 & 42 & 6 & 42 & 16 & 47 & 9 & 44 \\
Ondernemend & 11 & 37 & 0 & 47 & 3 & 47 & 4 & 44 \\
Risico's durven nemen & 21 & 21 & 6 & 24 & 3 & 6 & 9 & 15 \\
Commercieel inzicht & 16 & 32 & 12 & 29 & 0 & 47 & 7 & 38 \\
Flexibel, omgaan met veranderingen & 11 & 21 & 0 & 41 & 3 & 19 & 4 & 25 \\
Communicatief & 5 & 21 & 6 & 35 & 0 & 38 & 3 & 32 \\
Kennis kunnen delen & 11 & 16 & 0 & 24 & 3 & 31 & 4 & 25 \\
Vermogen om te leren & 0 & 16 & 0 & 35 & 3 & 19 & 2 & 22 \\
Organiseren en managen van projecten & 0 & 47 & 12 & 35 & 6 & 50 & 6 & 46 \\
Leidinggeven & 11 & 11 & 12 & 6 & 16 & 9 & 13 & 9 \\
Omgaan met andere disciplines & 0 & 26 & 0 & 35 & 3 & 31 & 2 & 31 \\
Ambitieus & 0 & 11 & 6 & 0 & 6 & 3 & 4 & 4 \\
Assertief & 11 & 11 & 6 & 6 & 31 & 0 & 19 & 4 \\
Creatief, innovatief & 0 & 42 & 0 & 29 & 0 & 34 & 0 & 35 \\
Werken in teamverband & 0 & 26 & 0 & 12 & 0 & 16 & 0 & 18 \\
Zelfstandig werken & 11 & 11 & 0 & 0 & 9 & 3 & 7 & 4 \\
Probleemoplossend vermogen & 0 & 21 & 0 & 18 & 3 & 13 & 2 & 16 \\
Geen van de competenties & 42 & & 35 & & 41 & & 40 &
\end{tabular}

* Maximaal 5 competenties konden worden genoemd. Percentage 'even belangrijk' is weggelaten. Bron: ROA Life Sciences Survey

\subsection{Cursussen en training}

Competenties worden onder andere verworven door het volgen van cursussen en trainingen. Op welk competentiegebieden volgen de hoogopgeleide werknemers in de Life Sciences cursussen en trainingen? Volgens tabel 6.3 zijn deze vooral gericht op het organiseren en managen van projecten en communicatie: de helft van de organisaties heeft zijn hoogopgeleiden een cursus in die richting laten volgen. Daarnaast worden cursussen gevolgd op het gebied van leiding geven (4I\%) en nog eens $31 \%$ van de organisaties stuurt zijn hoogopgeleide werknemers naar een cursus om hun commercieel inzicht te verbeteren. De gevolgde cursussen sluiten aan bij de toekomstige competentiebehoefte uit de vorige paragraaf (zie tabel 6.2). 


\section{Tabel 6.3}

Percentage bedrijven waar in de afgelopen 12 maanden op bepaalde competenties gerichte cursussen gevolgd zijn door hoogopgeleide werknemers in de Life Sciences (in procenten)

$\begin{array}{lrrrr} & \text { Kennis-instellingen } & \text { Grote bedrijven } & \text { MKB } & \text { Totaal } \\ \text { Fundamenteel onderzoek kunnen doen } & 47 & 6 & 0 & 15 \\ \text { Toegepast onderzoek kunnen doen } & 16 & 18 & 3 & 10 \\ \text { Ondernemend } & 26 & 35 & 13 & 22 \\ \text { Risico's durven nemen } & 0 & 6 & 3 & 3 \\ \text { Commercieel inzicht } & 32 & 47 & 22 & 31 \\ \text { Flexibel, omgaan met veranderingen } & 5 & 6 & 6 & 6 \\ \text { Communicatief } & 53 & 76 & 41 & 53 \\ \text { Kennis kunnen delen } & 16 & 6 & 3 & 7 \\ \text { Vermogen om te leren } & 0 & 0 & 3 & 1 \\ \text { Organiseren en managen van projecten } & 53 & 82 & 38 & 53 \\ \text { Leidinggeven } & 42 & 71 & 6 & 41 \\ \text { Omgaan met andere disciplines } & 11 & 12 & 0 & 9 \\ \text { Ambitieus } & 5 & 0 & 3 & 1 \\ \text { Assertief } & 5 & 0 & 9 & 3 \\ \text { Creatief, innovatief } & 5 & 12 & 9 & 9 \\ \text { Werken in teamverband } & 32 & 35 & 0 & 22 \\ \text { Zelfstandig werken } & 5 & 0 & 3 & 1 \\ \text { Probleemoplossend vermogen } & 26 & 6 & & 10 \\ \text { Bron: ROA Life Sciences Survey } & & & 6\end{array}$

\subsection{Het verwerven van competenties}

De opleiding en cursussen en trainingen op het werk zijn niet de enige manieren om competenties te verwerven. Competenties kunnen ook worden verworven door stages tijdens de opleiding, door te leren van collega's en gewoon door het enige tijd te doen (learning by doing). Volgens de organisaties in de Life Sciences leren de hoogopgeleide werknemers de meeste competenties vooral via formele training op het werk, via learning by doing en door te leren van collega's (zie figuur 6.4). Een uitzondering hierop vormen de competenties gericht op het doen van fundamenteel of toegepast onderzoek. Deze competenties worden vooral tijdens de studie en de stage verworven.

Tussen de soorten organisaties blijken enkele verschillen te bestaan. Zo vinden grote bedrijven relatief vaker dat competenties het beste tijdens de studie of stage geleerd kunnen worden. MKB bedrijven daarentegen vinden dat competenties vooral tijdens het werk geleerd kunnen worden. De organisaties zijn wel eensgezind over de competenties fundamenteel (en in iets minder mate toegepast) onderzoek. Die kunnen het beste tijdens studie of stage geleerd worden (zie de figuren B.2, B.3 en B.4 in de bijlagen). 


\section{Figuur 6.4}

Wijze van leren van competenties door hoopopgeleide werknemers in de Life Sciences (in procenten)

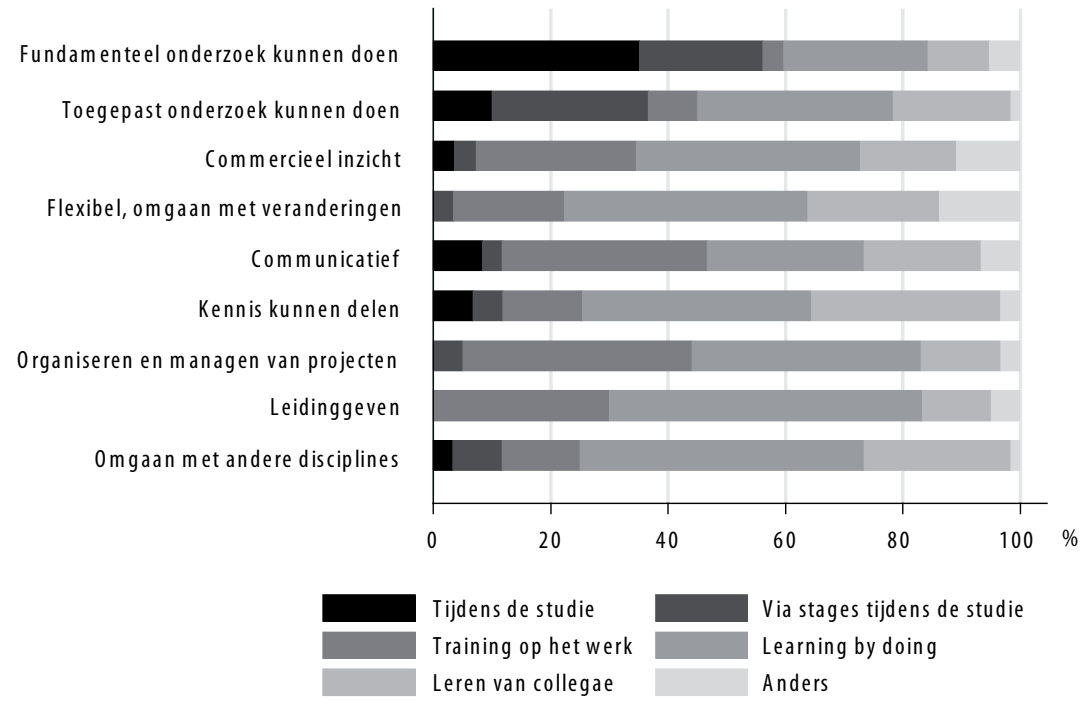

Bron: ROA Life Sciences Survey

Wat kun je wel en wat kun je niet leren? Generieke competenties (vooral de communicatiekant) "moet in de kiem aanwezig zijn" zegt een gesprekspartner uit een groot bedrijf, maar als er sollicitanten zijn die "veel hebben gedaan in hun opleiding aan bijvoorbeeld communicatie dan hebben ze een streepje voor". Onze gesprekspartner is tevens van mening dat "Je er meer uit kunt halen als je op die algemene competenties stuurt. Als je dat niet doet, heb je er later last van. Laat mensen van R\&D wat meer exposure krijgen in het bedrijf; hun wereld verbreden, meer ontwikkeling krijgen, dan durven mensen dat ook te laten zien." In zekere mate wijst de praktijk in het MKB op iets soortgelijks: "We laten mensen het hele bedrijf zien, zodat ze zien waar hun collega's vandaan komen." 



\section{Activiteiten, concurrentie en samenwerking}

In dit hoofdstuk wordt allereerst ingegaan op de verschillende activiteiten van de werknemers in de organisaties in de Life Sciences. Er wordt zowel gekeken naar de huidige activiteiten als naar verschuivingen in deze activiteiten die naar verwachting zullen optreden in de komende 5 en Io jaar. $\mathrm{Na}$ de activiteiten komen de mate van concurrentie en samenwerking aan bod zoals die op dit moment aanwezig zijn in de Life Sciences sector. Het hoofdstuk sluit af met een beschrijving van de bereidheid tot samenwerking in de komende 5 jaar.

\subsection{Activiteiten nu en in de toekomst}

\section{Huidige activiteiten}

Werknemers in de Life Sciences organisaties houden zich het meeste bezig met activiteiten die gericht zijn op toegepast onderzoek: drie kwart van de Life Sciences organisaties geeft aan dat hun werknemers zich in (sterke) mate met deze activiteiten bezig houden (zie tabel 7.I). Volgens $38 \%$ van de organisaties zijn hun werknemers in (sterke) mate bezig met activiteiten gericht op fundamenteel onderzoek en bij 31\% van de organisaties werken hun medewerkers vooral aan clinical trials \& analyse.

Zoals te verwachten is, zijn de activiteiten van de werknemers in kennisinstellingen in sterkere mate gericht op fundamenteel onderzoek dan bij de andere twee soorten organisaties ( $74 \%$ tegenover $30 \%$ en $23 \%$ ). Toegepast onderzoek vindt daarentegen relatief meer plaats bij grote bedrijven (95\%) dan bij kennisinstellingen en het MKB (77\% en 64\%). De activiteiten van de werknemers van de MKB bedrijven zijn in relatief sterkere mate gericht op productie (3I\%) en op marketing, verkoop en service (42\%) dan bij de grote bedrijven en kennisinstellingen. 
Tabel 7.1

Mate waarin werknemers in de Life Sciences activiteiten verrichten op verschillende gebieden (in procenten)

\begin{tabular}{|c|c|c|c|c|}
\hline & \multicolumn{3}{|c|}{ Soort bedrijf } & \multirow[b]{2}{*}{ Totaal } \\
\hline & Kennisinstellingen & Grote bedrijven & MKB & \\
\hline \multicolumn{5}{|c|}{ Fundamenteel onderzoek } \\
\hline Helemaal niet & 11 & 50 & 54 & 42 \\
\hline Neutraal & 16 & 20 & 23 & 20 \\
\hline In sterke mate & 74 & 30 & 23 & 38 \\
\hline Totaal & 100 & 100 & 100 & 100 \\
\hline \multicolumn{5}{|c|}{ Toegepast onderzoek } \\
\hline Helemaal niet & 0 & 5 & 22 & 11 \\
\hline Neutraal & 23 & 0 & 14 & 13 \\
\hline In sterke mate & 77 & 95 & 64 & 76 \\
\hline Totaal & 100 & 100 & 100 & 100 \\
\hline \multicolumn{5}{|c|}{ Clinical trials \& analyse } \\
\hline Helemaal niet & 48 & 58 & 46 & 49 \\
\hline Neutraal & 19 & 21 & 20 & 20 \\
\hline In sterke mate & 33 & 21 & 34 & 31 \\
\hline Totaal & 100 & 100 & 100 & 100 \\
\hline \multicolumn{5}{|l|}{ Productie } \\
\hline Helemaal niet & 75 & 79 & 46 & 62 \\
\hline Neutraal & 10 & 5 & 23 & 15 \\
\hline In sterke mate & 15 & 16 & 31 & 23 \\
\hline Totaal & 100 & 100 & 100 & 100 \\
\hline \multicolumn{5}{|c|}{ Marketing, verkoop \& service } \\
\hline Helemaal niet & 81 & 68 & 42 & 59 \\
\hline Neutraal & 5 & 16 & 17 & 13 \\
\hline In sterke mate & 14 & 16 & 42 & 28 \\
\hline Totaal & 100 & 100 & 100 & 100 \\
\hline
\end{tabular}

\section{Toekomstige verschuiving in de activiteiten}

Tabel 7.2 laat zien dat een ruime meerderheid van de organisaties in de Life Sciences denkt dat hun werknemers de komende 5 jaar net zo veel met fundamenteel onderzoek bezig zullen zijn als nu. Wat betreft toegepast onderzoek zijn de meningen verdeeld. Het ene deel van de organisaties denkt dat hun werknemers zich net zo veel met toegepast onderzoek zullen bezig houden als nu. Het andere deel denkt juist dat de werknemers zich meer op toegepast onderzoek zullen gaan toeleggen in de komende 5 jaar. De helft van de grote bedrijven en MKB bedrijven verwacht dat hun werknemers 
in toenemende mate activiteiten zullen verrichten die gericht zijn op clinical trials $\&$ analyse. Bij de kennisbedrijven ligt dit percentage iets lager en bijna de helft van hen verwacht geen verandering. De helft van het MKB denkt dat hun werknemers in meerdere mate dan nu het geval is activiteiten zullen uitvoeren die gericht zijn op productie en marketing, verkoop en service. De meerderheid van de kennisinstellingen en grote bedrijven verwacht juist dat hun werknemers zich in dezelfde mate als nu met dergelijke activiteiten zullen bezig houden. Het beeld betreffende veranderingen in de activiteiten in de komende Io jaar (zie tabel B.9 in de bijlage) komt overeen met dat over de komende 5 jaar en wordt hier niet verder besproken.

\section{Tabel 7.2}

Mate waarin de activiteiten van werknemers in de Life Sciences de komende 5 jaar meer of minder aandacht zullen krijgen (in procenten)

\begin{tabular}{|c|c|c|c|c|}
\hline \multirow{3}{*}{ Fundamenteel onderzoek } & \multicolumn{3}{|c|}{ Soort bedrijf } & \multirow[b]{2}{*}{ Totaal } \\
\hline & \multirow[t]{2}{*}{ Kennisinstellingen } & \multirow[t]{2}{*}{ Grote bedrijven } & \multirow[t]{2}{*}{ MKB } & \\
\hline & & & & \\
\hline (Veel) minder dan nu & 0 & 20 & 21 & 15 \\
\hline Zelfde als nu & 63 & 70 & 61 & 64 \\
\hline (Veel) meer dan nu & 37 & 10 & 18 & 21 \\
\hline Totaal & 100 & 100 & 100 & 100 \\
\hline \multicolumn{5}{|l|}{ Toegepast onderzoek } \\
\hline (Veel) minder dan nu & 0 & 5 & 9 & 5 \\
\hline Zelfde als nu & 43 & 43 & 50 & 46 \\
\hline (Veel) meer dan nu & 57 & 52 & 41 & 49 \\
\hline Totaal & 100 & 100 & 100 & 100 \\
\hline \multicolumn{5}{|l|}{ Clinical trials \& analyse } \\
\hline (Veel) minder dan nu & 10 & 16 & 21 & 16 \\
\hline Zelfde als nu & 48 & 32 & 29 & 35 \\
\hline (Veel) meer dan nu & 43 & 53 & 50 & 49 \\
\hline Totaal & 100 & 100 & 100 & 100 \\
\hline \multicolumn{5}{|l|}{ Productie } \\
\hline (Veel) minder dan nu & 15 & 26 & 21 & 21 \\
\hline Zelfde als nu & 55 & 58 & 30 & 44 \\
\hline (Veel) meer dan nu & 30 & 16 & 48 & 35 \\
\hline Totaal & 100 & 100 & 100 & 100 \\
\hline \multicolumn{5}{|c|}{ Marketing, verkoop \& service } \\
\hline (Veel) minder dan nu & 9 & 21 & 12 & 13 \\
\hline Zelfde als nu & 59 & 58 & 38 & 49 \\
\hline (Veel) meer dan nu & 32 & 21 & 50 & 37 \\
\hline Totaal & 100 & 100 & 100 & 100 \\
\hline
\end{tabular}




\section{Toekomstige verplaatsing van activiteiten}

Van bovengenoemde activiteiten is ook onderzocht of deze in de toekomst verplaatst zullen worden naar een ander land of regio. Tabel 7.3 geeft een beeld van de verwachte verplaatsing van activiteiten door organisaties in de Life Sciences in de komende 5 jaar. Uit deze tabel blijkt dat slechts een kwart van organisaties intenties heeft om in de toekomst hun fundamenteel onderzoek te verplaatsen. Een iets groter percentage $(32 \%)$ geeft aan plannen te hebben voor het verhuizen van hun toegepaste onderzoek. Het MKB verwacht relatief minder vaak en de grote bedrijven relatief vaker dat ze onderzoeksactiviteiten zullen verplaatsen naar een ander land of regio in de komende 5 jaar.

Wat betreft clinical trials en analyse zijn het vooral de grote bedrijven die verwachten dat zij deze activiteiten zullen verplaatsen in de nabije toekomst (83\%). Van de kennisinstellingen verwacht iets minder dan de helft dat activiteiten gericht op clinicial trials en analyse verplaatst zullen worden. Daarentegen denkt slechts $15 \%$ van het MKB aan het verplaatsen van deze activiteiten. Een analyse van de activiteiten productie en marketing, verkoop en service levert een vergelijkbaar beeld op: meer dan de helft van de grote bedrijven ziet wel brood in een dergelijke verplaatsing, terwijl van het MKB hooguit een derde overweegt om deze activiteiten te verplaatsen. De verwachting van de kennisinstellingen ligt hier ergens tussen in. Wanneer de organisaties wordt gevraagd welk land of regio hun voorkeur heeft, dan worden Azië en de Verenigde Staten relatief vaak genoemd.

Tabel 7.3

Percentage organisaties dat verwacht de activiteiten in de komende 5 jaar naar een ander land of regio te verplaatsen (in procenten)

\begin{tabular}{lrrrr} 
& \multicolumn{3}{c}{ Soort bedrijf } & \\
& Kennisinstellingen & Grote bedrijven & MKB & Totaal \\
Fundamenteel onderzoek & 26 & 38 & 15 & 25 \\
Toegepast onderzoek & 30 & 47 & 23 & 32 \\
Clinical trials \& analyse & 47 & 83 & 15 & 42 \\
Productie & 42 & 55 & 36 & 42 \\
Marketing, verkoop \& service & 50 & 77 & 15 & 39 \\
Bron: ROA Life Sciences Survey & & & &
\end{tabular}

Wanneer de arbeidsorganisaties wordt gevraagd naar hun toekomstplannen met betrekking op het verplaatsen van activiteiten in de komende tien jaar, dan wordt het geschetste beeld wat meer diffuus (zie tabel 7.4). Slechts I3\% van de kennisinstellingen verwacht het fundamentele onderzoek te verplaatsen en I $8 \%$ het toegepaste onderzoek. Bij de andere activiteiten gericht op clinical trials \& analyse, productie en marketing, verkoop \& service verwacht telkens ongeveer $40 \%$ van de kennisinstellingen dat deze activiteiten wel verplaatst zullen worden in de komende io jaar. Een even groot percentage verwacht echter dat deze activiteiten niet verplaatst zullen worden. De rest heeft daar nu nog geen zicht op. 
De grote bedrijven hebben niet altijd zicht op de verwachte verplaatsing van hun activiteiten: een kwart van hen geeft bij de meeste activiteiten aan niet te weten of deze verplaatst zullen worden in de komende Io jaar. Ongeveer 30\% van de grote bedrijven verwacht het fundamenteel onderzoek de komende io jaar te verplaatsen. Bij toegepast onderzoek ligt dit percentage veel hoger: de helft van de grote bedrijven verwacht deze activiteiten te verplaatsen. Bij de activiteiten gericht op clinical trial en analyse, productie en marketing, verkoop en service neemt de verwachte kans op verplaatsing door de grote bedrijven toe: ongeveer $60 \%$ van hen denkt deze activiteiten op de lange termijn te zullen verplaatsen naar een ander land of regio.

\section{Tabel 7.4}

Percentage organisaties dat verwacht de activiteiten naar een ander land of regio te verplaatsen in de komende 10 jaar (in procenten)*

\begin{tabular}{|c|c|c|c|c|}
\hline & \multicolumn{3}{|c|}{ Soort bedrijf } & Totaal \\
\hline \multicolumn{5}{|l|}{ Fundamenteel onderzoek } \\
\hline Ja & 13 & 31 & 5 & 14 \\
\hline Daar heb ik nu geen zicht op & 13 & 31 & 35 & 27 \\
\hline \multicolumn{5}{|l|}{ Toegepast onderzoek } \\
\hline Ja & 18 & 53 & 24 & 31 \\
\hline Daar heb ik nu geen zicht op & 12 & 27 & 19 & 19 \\
\hline \multicolumn{5}{|l|}{ Clinical trials $\&$ analyse } \\
\hline Ja & 46 & 59 & 30 & 42 \\
\hline Daar heb ik nu geen zicht op & 15 & 33 & 15 & 20 \\
\hline \multicolumn{5}{|l|}{ Productie } \\
\hline Ja & 42 & 60 & 38 & 44 \\
\hline Daar heb ik nu geen zicht op & 17 & 20 & 24 & 21 \\
\hline \multicolumn{5}{|l|}{ Marketing, verkoop \& service } \\
\hline Ja & 41 & 60 & 19 & 35 \\
\hline $\begin{array}{l}\text { Daar heb ik nu geen zicht op } \\
\text { * De restcategorie "Nee" is }\end{array}$ & $\begin{array}{c}17 \\
\text { deze tabel opger }\end{array}$ & 30 & 19 & 21 \\
\hline
\end{tabular}

Het MKB heeft nauwelijks plannen om fundamenteel onderzoek te verplaatsen in de komende tien jaar, terwijl een kwart er wel over denkt om het toegepast onderzoek te verhuizen. Clinical trials $\&$ analyse en de productie staan binnen het MKB nog het hoogst op het lijstje van te verplaatsen activiteiten: $30 \%$ en $38 \%$ van de MKB bedrijven verwachten deze activiteiten te verplaatsen. Echter, vrijwel eenzelfde percentages MKB bedrijven wil deze activiteiten niet verplaatsen. Bovendien heeft lang niet elk MKB bedrijf op dit moment zicht op deze ontwikkelingen. 


\subsection{Concurrentie en samenwerking}

\section{Concurrentie}

Life Sciences organisaties in Zuidoost Nederland stellen dat hun concurrentie voornamelijk uit het buitenland komt. Tabel 7.5 laat zien dat van $75 \%$ van de organisaties de belangrijkste concurrent buiten Nederland gevestigd is. Relatief het vaakst worden de vestigingslanden Verenigde Staten en in iets mindere mate Duitsland genoemd. De grote bedrijven hebben relatief meer met buitenlandse concurrentie te maken dan de kennisinstellingen en het MKB. De organisaties van wie hun belangrijkste concurrent in Nederland gevestigd is, hebben in twee derde van de gevallen te maken met een concurrent die buiten hun eigen regio gevestigd is.

Tabel 7.5

Locatie van belangrijkste concurrent (in procenten)

\begin{tabular}{lrrrr|} 
& Kennisinstellingen & Grote bedrijven & MKB & Totaal \\
In Nederland & 22 & 11 & 35 & 25 \\
In het buitenland & 78 & 89 & 65 & 75 \\
Totaal & 100 & 100 & 100 & 100 \\
Bron: ROA Life Sciences Survey & & & &
\end{tabular}

\section{Samenwerking}

Wat betreft samenwerking wordt door de Life Sciences organisaties bij voorkeur samengewerkt op het gebied van R\&D met universiteiten, hoge scholen en andere bedrijven (zie figuur 7.I). Relatief het minst wordt samengewerkt met andere bedrijven op het gebied van uitwisseling en training van personeel. Kennisinstellingen en het MKB werken relatief meer samen met universiteiten, hogescholen en andere bedrijven dan grote bedrijven om hun strategie voor de toekomst te bepalen. Een mogelijke verklaring hiervoor is dat grote bedrijven genoeg experts in huis hebben om dit zelf te kunnen doen. Grote bedrijven op hun beurt werken weer iets vaker samen met de provincie om een toekomststrategie te bepalen dan de kennisinstellingen en het MKB. 
Figuur 7.1

Mate van samenwerking met andere organisaties in de regio op diverse terreinen (in procenten)

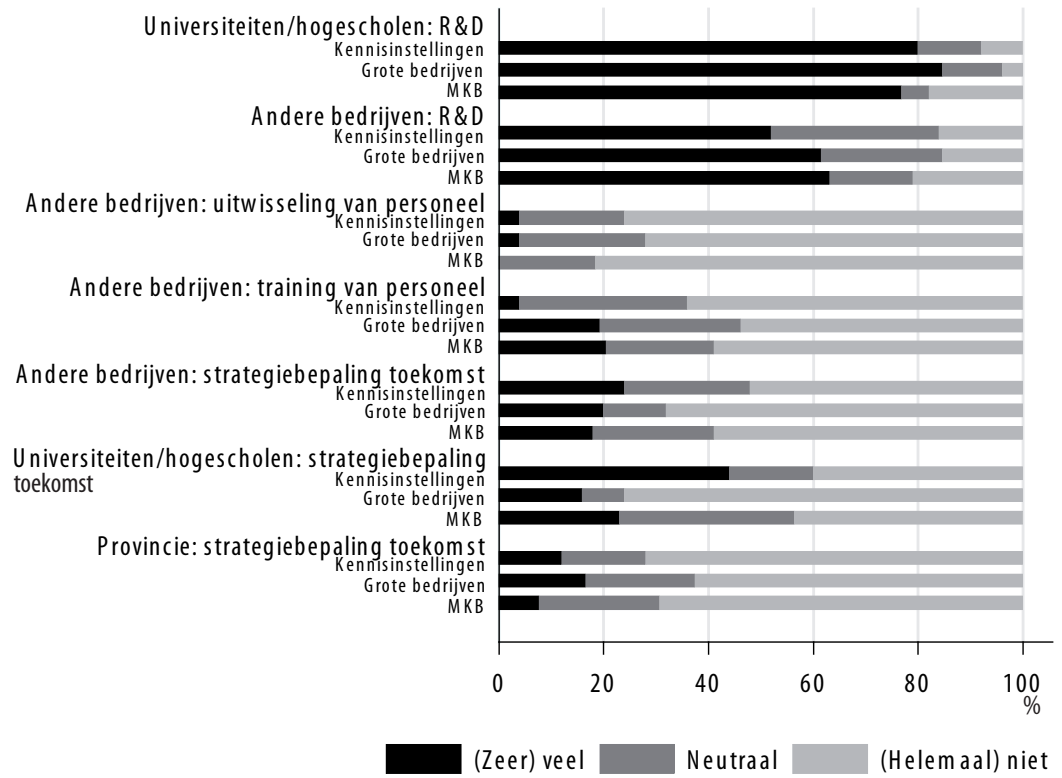

Bron: ROA Life Sciences Survey

Hoewel uit de vorige figuur is gebleken dat er op een aantal terrein weinig door Life Sciences organisaties wordt samengewerkt, is de bereidheid tot samenwerking wel degelijk aanwezig. Volgens figuur 7.2 is de bereidheid tot samenwerking op alle terreinen voor alle soorten organisaties groter dan de huidige daadwerkelijke samenwerking uit figuur 7.I.

Een grote meerderheid van de organisaties is bereid om samen te werken met universiteiten, hoge scholen en andere bedrijven op het gebied van R\&D. Verder is ongeveer de helft van de organisaties bereid om met universiteiten en hoge scholen samen te werken bij het bepalen van hun toekomstige strategie. Figuur 7.2 maakt echter wel duidelijk dat die bereidheid per soort organisatie verschilt: de kennisinstellingen vertonen relatief de grootste bereidheid en de grote bedrijven de kleinste. Dit patroon is ook zichtbaar bij de bereidheid tot samenwerking op de andere terreinen.

Bij kennisinstellingen wordt gewerkt aan de samenwerking met Leuven en Aken op het gebied van personeel ("We hebben meerder mensen die op meerdere plaatsen werken"), maar dit gaat niet vanzelf: "Het is daar echt anders, dat is belangrijk om vast te stellen". Samenwerking is gezien de ontwikkelingen in de Life Sciences een noodzaak: "Je kunt 
niet meer alleen dit soort onderzoek doen, de ontwikkelingen gaan razendsnel en op topniveau moet je samenwerken. Je wordt er altijd beter van".

In de gesprekken blijkt dat er verschillend wordt nagedacht over samenwerking met de provincie. Deze verschillen illustreren de bevindingen uit de enquête. Een groot bedrijf: "Wat levert samenwerking met de provincie op behalve meer vergaderen? Er moet niet teveel alleen maar gepraat worden." Het MKB vindt de samenwerking met de provincie van belang, maar tegelijkertijd ook "te traag". Kennisinstellingen zijn positiever over mogelijkheden voor samenwerking: "de provincie zou een gezamenlijk plan de campagne kunnen initiëren". Daarbij zouden keuzes moeten worden gemaakt: op welke gebieden van de Life Sciences gaan we ons richten (hart/vaten, vergrijzing, voeding, ...). Tegelijkertijd zijn er ook kritische geluiden richting de grote bedrijven die te weinig zouden doen in termen van samenwerking met anderen: bijvoorbeeld door "financiering van onderzoek en inzetten van de brains die ze hebben". Er liggen op het terrein van samenwerking kennelijk voldoende kansen.

Ook het MKB ziet wel brood in samenwerking op het terrein van een arbeidspool: "Wat $i k$ belangrijk vind is dat we beginnen met een arbeidspool, zodat we niet elkaars personeel afsnoepen. Als dit gebeurt, leidt dit tot hogere salariseisen bij de mensen die achterblijven. Het liefst wil je natuurlijk de mensen die je zelfopleidt ook zelf houden". Als het gaat om samenwerking erkent het $\mathrm{MKB}$ een potentieel probleem: " $M K B$ zou wel willen [samenwerken], maar je moet eerst een trackrecord opbouwen voordat de grote bedrijven mee willen doen". 


\section{Figuur 7.2}

Bereidheid tot samenwerking in de komende 5 jaar met andere organisaties in de regio op diverse terreinen (in procenten)

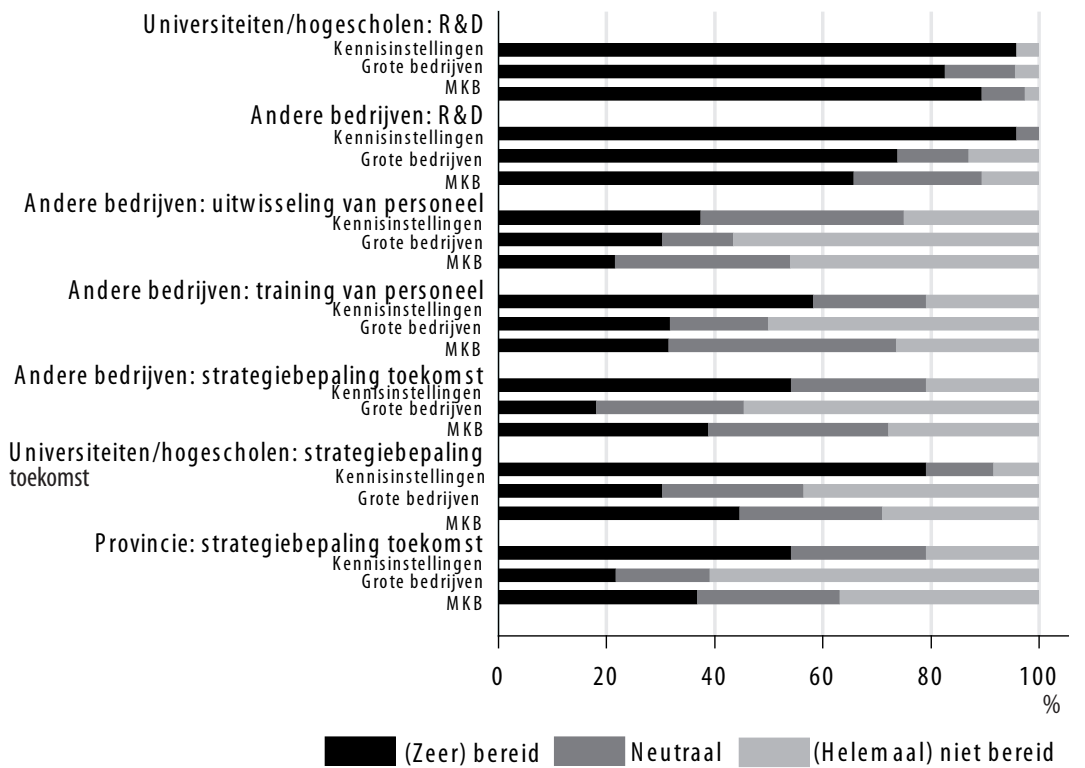

Bron: ROA Life Sciences Survey 



\section{Bijlage: aanvullende tabellen en figuren}

\section{Tabel B.1}

In welke mate ervaart u problemen bij het vinden van werknemers in de Life Sciences op MBO niveau, nu of in de afgelopen 12 maanden (in procenten)*

$\begin{array}{lr} & \% \\ 1 \text { geen problemen } & 14 \\ 3 & 22 \\ 4 & 36 \\ 5 \text { erg veel problemen } & 14 \\ \text { Totaal } & 14 \\ \text { Gemiddelde } & 100 \\ \text { * Merk op dat het aantal waarneming laag is: } \mathrm{n}=14 & 2,9 \\ \text { Bron: } \text { ROA Life Sciences Survey } & \end{array}$

Tabel B.2

Wat zijn/waren de direct merkbaren problemen van het moeilijk kunnen vinden van hoogopgeleide werknemers in de Life Sciences (in procenten)

$\begin{array}{lrrrr} & \text { Kennisinstelling } & \text { Grote bedrijven } & \text { MKB } & \text { Totaal } \\ \text { Toegenomen werkdruk } & 53 & 64 & 61 & 59 \\ \text { Werk blijt liggen } & 65 & 71 & 67 & 67 \\ \text { Levertijden worden langer } & 0 & 0 & 0 & 0 \\ \text { Slechtere concurrentiepositie } & 35 & 21 & 28 & 29 \\ \text { Minder mogelijkheden om te innoveren } & 29 & 79 & 61 & 55 \\ \text { Vermindering v d kwaliteit v d productie } & 18 & 0 & 11 & 10 \\ \text { Verlies van orders } & 6 & 7 & 17 & 10 \\ \text { Hogere wervings- \& opleidingskosten } & 24 & 14 & 28 & 22 \\ \text { Anders } & 12 & 7 & 0 & 6\end{array}$

\section{Tabel B.3}

Kwalitatief of kwantitatief tekort aan werknemers in de Life Sciences op MBO niveau, naar soort bedrijf (in procenten)

$\begin{array}{lrrrr} & \text { Kennisinstellingen } & \text { Grote bedrijven } & \text { MKB } & \text { Totaal } \\ \text { Nee } & 63 & 94 & 70 & 74 \\ \text { Ja, een kwalitatief tekort } & 10 & 0 & 6 & 6 \\ \text { Ja, een kwantitatief tekort } & 10 & 6 & 15 & 11 \\ \text { Ja, zowel een kwalitatief als een } & 17 & 0 & 9 & 9 \\ \text { kwantitatief tekort } & & & 100 & 100 \\ \text { Totaal } & 100 & 100 & & \end{array}$


Tabel B.4

Gebruik van wervingsinstrumenten voor het werven van hoogopgeleide werknemers in de Life Sciences, naar soort organisatie (gemiddelde score)*

$\begin{array}{lrrr} & \text { Kennis-instellingen } & \text { Grote bedrijven } & \text { MKB } \\ \text { Via wervingsadvertentie } & 2.3 & 2.5 & 2.1 \\ \text { Via het eigen personeel } & 2.8 & 2.5 & 2.4 \\ \text { Via het eigen netwerk } & 3.0 & 2.7 & 2.5 \\ \text { Via universiteiten, hogescholen (bv. stage) } & 2.8 & 2.8 & 2.2 \\ \text { Via uitzendbureaus } & 1.4 & 2.2 & 1.6 \\ \text { Via commerciële wervingsbureaus } & 1.4 & 1.9 & 1.7 \\ \text { Via internet } & 2.4 & 2.8 & 2.2 \\ \text { Via werkzoekend die zichzelf aanbieden (open sollicitaties) } & 2.4 & 2.8 & 2.2 \\ \text { Werven in het buitenland } & 2.3 & 2.4 & 1.6 \\ \text { *Gemiddeld van 1:'nooit'; 2:' 'soms'; 3:'vaak of altijd' } & & & \end{array}$

Bron: ROA Life Sciences Survey

\section{Figuur B.1}

Ervaring over effectiviteit van wervingsinstrumenten (in procenten)

Via wervingsadvertentie

Via het eigen personeel

Via het eigen netwerk

Via universiteiten, hogescholen (bv. stages)

Via uitzendbureaus

Via com merciele wervingsbureaus

Via internet

Via werkzoekend die zichzelf aanbieden

(open sollicitaties)

W erven in het buitenland
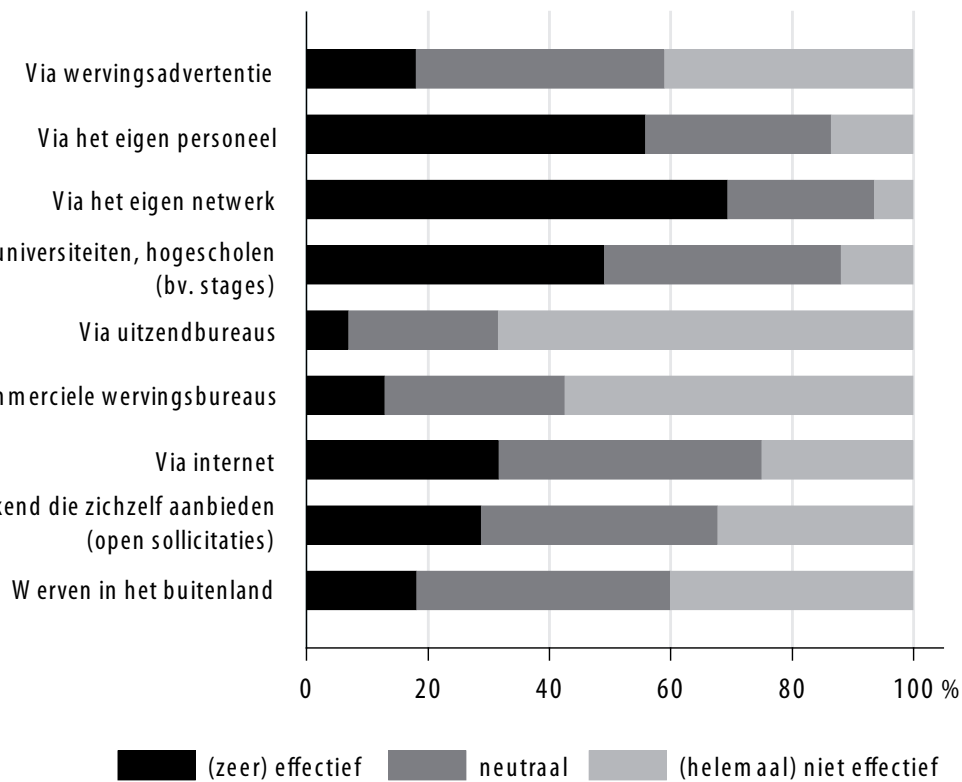

(zeer) effectief

neutraal

(helem aal) niet effectief

Bron: ROA Life Sciences Survey 
Tabel B.5

Ervaring over effectiviteit van wervingsinstrumenten, naar soort organisatie (gemiddelde score)*

$\begin{array}{lrrr} & \text { Kennis-instellingen } & \text { Grote bedrijven } & \text { MKB } \\ \text { Via wervingsadvertentie } & 2.4 & 2.7 & 2.7 \\ \text { Via het eigen personeel } & 3.8 & 3.8 & 3.4 \\ \text { Via het eigen netwerk } & 4.2 & 4.2 & 3.6 \\ \text { Via universiteiten, hogescholen (bv. stage) } & 3.7 & 3.9 & 2.9 \\ \text { Via uitzendbureaus } & 1.9 & 2.4 & 2.0 \\ \text { Via commerciële wervingsbureaus } & 1.9 & 2.6 & 2.3 \\ \text { Via internet } & 3.1 & 3.1 & 3.0 \\ \text { Via werkzoekend die zichzelf aanbieden (open } & 2.9 & 3.6 & 2.8 \\ \text { sollicitaties) } & & & 2.3 \\ \text { Werven in het buitenland } & 2.8 & 3.2 & \end{array}$

* Gemiddelde op schaal van 1: "helemaal niet effectief" tot 5 "zeer effectief"

Bron: ROA Life Sciences Survey

\section{Tabel B.6}

Disciplines van hoogopgeleide werknemers in de Life Sciences die momenteel het meest relevant zijn voor de organisaties, naar soort organisatie (percentage genoemd en cijfer)

\begin{tabular}{|c|c|c|c|c|}
\hline & & Kennisinstellingen & Grote bedrijven & MKB \\
\hline \multirow[t]{2}{*}{ Chemie } & Genoemd (\%) & 13 & 37 & 24 \\
\hline & Waardering (cijfer) & 3.7 & 4.1 & 3.4 \\
\hline \multirow[t]{2}{*}{ Biochemie } & Genoemd (\%) & 48 & 32 & 32 \\
\hline & Waardering (cijfer) & 3.4 & 3.0 & 3.5 \\
\hline \multirow[t]{2}{*}{ Chemische analyse } & Genoemd (\%) & 4 & 26 & 6 \\
\hline & Waardering (cijfer) & 3.0 & 3.2 & 3.0 \\
\hline \multirow[t]{2}{*}{ Polymeerchemie } & Genoemd (\%) & 13 & 26 & 6 \\
\hline & Waardering (cijfer) & 3.3 & 3.6 & 4.5 \\
\hline \multirow[t]{2}{*}{ Biometrie } & Genoemd (\%) & 9 & 5 & 15 \\
\hline & Waardering (cijfer) & 2.0 & 5.0 & 3.0 \\
\hline \multirow[t]{2}{*}{ Biotechno., mol. biologie } & Genoemd (\%) & 61 & 47 & 29 \\
\hline & Waardering (cijfer) & 3.9 & 3.8 & 3.4 \\
\hline \multirow[t]{2}{*}{ Nanotechnologie, bioelectronica } & Genoemd (\%) & 26 & 21 & 21 \\
\hline & Waardering (cijfer) & 2.3 & 1.8 & 2.9 \\
\hline \multirow[t]{2}{*}{ Microbiologie, bacteriologie } & Genoemd (\%) & 13 & 16 & 18 \\
\hline & Waardering (cijfer) & 2.0 & 2.7 & 3.5 \\
\hline \multirow[t]{2}{*}{ Natuurkunde, plantkunde } & Genoemd (\%) & 4 & 5 & 0 \\
\hline & Waardering (cijfer) & 1.0 & 5.0 & \\
\hline \multirow[t]{2}{*}{ Materiaalkunde } & Genoemd (\%) & 13 & 11 & 6 \\
\hline & Waardering (cijfer) & 2.3 & 3.5 & 2.0 \\
\hline \multirow[t]{2}{*}{ Biofysica } & Genoemd (\%) & 30 & 21 & 6 \\
\hline & Waardering (cijfer) & 3.0 & 1.8 & 5.0 \\
\hline \multirow[t]{2}{*}{ Farmacologie } & Genoemd (\%) & 17 & 26 & 21 \\
\hline & Waardering (cijfer) & 2.8 & 3.2 & 2.7 \\
\hline \multirow[t]{2}{*}{ Biomedisch } & Genoemd (\%) & 74 & 47 & 43 \\
\hline & Waardering (cijfer) & 4.2 & 3.2 & 3.9 \\
\hline \multirow[t]{2}{*}{ Medische fysica e.d. } & Genoemd (\%) & 17 & 16 & 21 \\
\hline & Waardering (cijfer) & 3.3 & 1.3 & 3.6 \\
\hline \multirow[t]{2}{*}{ Toxicologie } & Genoemd (\%) & 17 & 21 & 6 \\
\hline & Waardering (cijfer) & 2.5 & 2.0 & 3.0 \\
\hline \multirow[t]{2}{*}{ Voedingskunde, levensmiddelen techno. } & Genoemd (\%) & 0 & 5 & 12 \\
\hline & Waardering (cijfer) & & 1.0 & 2.3 \\
\hline \multirow[t]{2}{*}{ Anders } & Genoemd (\%) & 13 & 11 & 35 \\
\hline & Waardering (cijfer) & 3.0 & 1.5 & 4.5 \\
\hline
\end{tabular}




\section{Tabel B.7}

Disciplines van hoogopgeleide werknemers in de Life Sciences waar in de komende 5 jaar de meeste behoefte aan zal zijn, naar soort organisatie (percentage organisaties dat discipline noemt)*

$\begin{array}{lrrr} & \text { Kennisinstellingen } & \text { Grote bedrijven } & 8 \\ \text { Chemie } & 5 & 26 & 28 \\ \text { Biochemie } & 48 & 26 & 11 \\ \text { Chemische analyse } & 0 & 21 & 8 \\ \text { Polymeerchemie } & 10 & 42 & 8 \\ \text { Biometrie } & 14 & 5 & 25 \\ \text { Biotechno., mol. biologie } & 48 & 37 & 19 \\ \text { Nanotechnologie, bioelectronica } & 19 & 26 & 17 \\ \text { Microbiologie, bacteriologie } & 5 & 16 & 3 \\ \text { Natuurkunde, plantkunde } & 5 & 5 & 6 \\ \text { Materiaalkunde } & 5 & 16 & 6 \\ \text { Biofysica } & 14 & 11 & 8 \\ \text { Farmacologie } & 14 & 26 & 39 \\ \text { Biomedisch } & 76 & 68 & 14 \\ \text { Medische fysica e.d. } & 14 & 21 & 6 \\ \text { Toxicologie } & 0 & 21 & 8 \\ \text { Voedingskunde, levensm. techno. } & 0 & 0 & 33 \\ \text { Anders } & 14 & 11 & 11 \\ \text { Daar heb ik geen zicht op } & 0 & 5 & \\ \text { * Maximaal 5 konden worden genoemd } & & & 3 \\ \text { Bron: ROA Life Sciences Survey } & & & \\ \end{array}$

\section{Figuur B.2}

Wijze van leren van competenties door hoopopgeleide werknemers in de Life Sciences, kennisinstellingen (in procenten)

Fundamenteel onderzoek kunnen doen

Toegepast onderzoek kunnen doen

Commercieel inzicht

Flexibel, om gaan met veranderingen

Communicatief

Kennis kunnen delen

Organiseren en managen van projecten

Leidinggeven

Leidinggeven
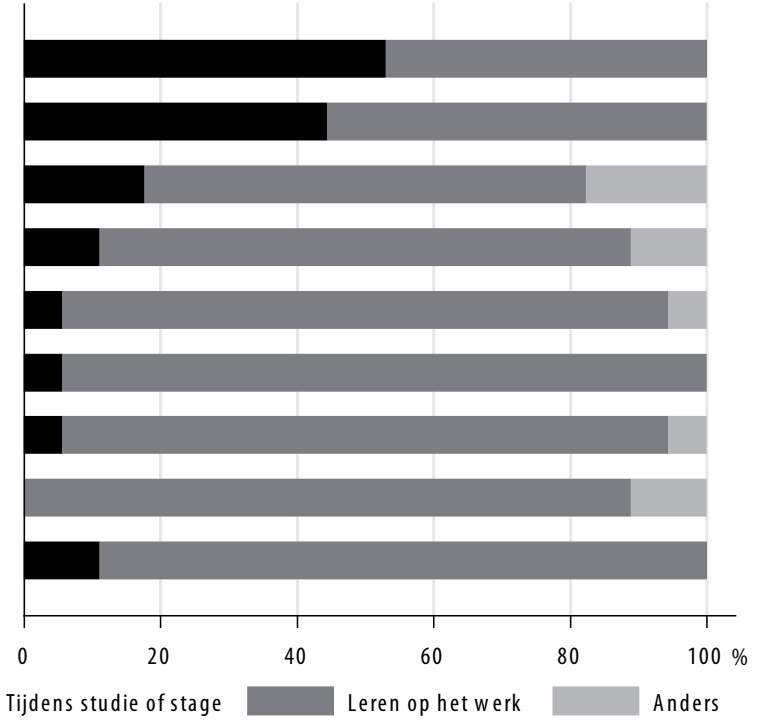

Bron: ROA Life Sciences Survey 


\section{Tabel B.8}

Disciplines van hoogopgeleide werknemers in de Life Sciences waar in de komende 5 jaar de minst behoefte aan zal zijn, naar soort organisatie (percentage organisaties dat discipline noemt)*

$\begin{array}{lrrr} & \text { Kennisinstellingen } & \text { Grote bedrijven } & 11 \\ \text { Chemie } & 19 & 5 & 3 \\ \text { Biochemie } & 5 & 0 & 19 \\ \text { Chemische analyse } & 24 & 21 & 25 \\ \text { Polymeerchemie } & 52 & 21 & 19 \\ \text { Biometrie } & 33 & 26 & 8 \\ \text { Biotechno., mol. biologie } & 5 & 5 & 11 \\ \text { Nanotechnologie, bioelectronica } & 10 & 21 & 17 \\ \text { Microbiologie, bacteriologie } & 14 & 16 & 25 \\ \text { Natuurkunde, plantkunde } & 38 & 58 & 22 \\ \text { Materiaalkunde } & 38 & 37 & 6 \\ \text { Biofysica } & 10 & 11 & 3 \\ \text { Farmacologie } & 0 & 26 & 3 \\ \text { Biomedisch } & 5 & 0 & 3 \\ \text { Medische fysica e.d. } & 14 & 21 & 6 \\ \text { Toxicologie } & 14 & 16 & 17 \\ \text { Voedingskunde, levensm. techno. } & 19 & 53 & 0 \\ \text { Anders } & 5 & 0 & 33 \\ \text { Daar heb ik geen zicht op } & 14 & 5 & \\ \text { * Maximaal 5 disciplines konden worden genoemd } & & & 3 \\ \text { Bron: ROA Life Sciences Survey } & & 5 & \\ \end{array}$

\section{Figuur B.3}

Wijze van leren van competenties door hoopopgeleide werknemers in de Life Sciences, grote bedrijven (in procenten)

\section{Fundam enteel onderzoek kunnen doen}

Toegepast onderzoek kunnen doen

Com mercieel inzicht

Flexibel, om gaan met veranderingen

Communicatief

Kennis kunnen delen

Organiseren en managen van projecten

Leidinggeven

$0 \mathrm{mgaan}$ met andere disciplines

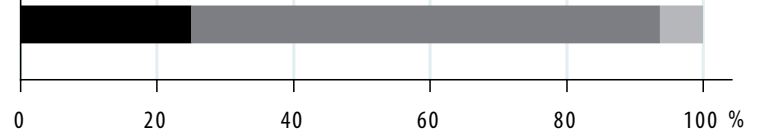

Tijdens studie of stage

Bron: ROA Life Sciences Survey 


\section{Figuur B.4}

Wijze van leren van competenties door hoopopgeleide werknemers in de Life Sciences, MKB (in procenten)

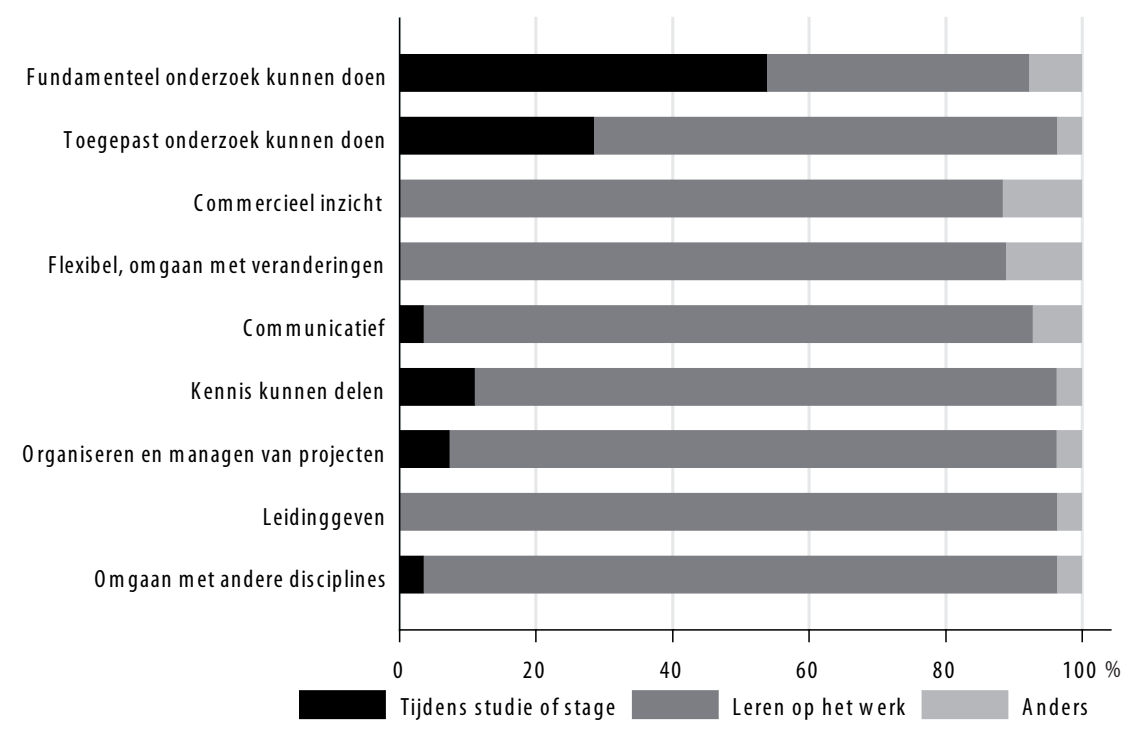

Bron: ROA Life Sciences Survey 
Tabel B.9

Mate waarin de activiteiten van werknemers in de Life Sciences in de komende 10 jaar meer of minder gericht zullen zijn op ... (in procenten)

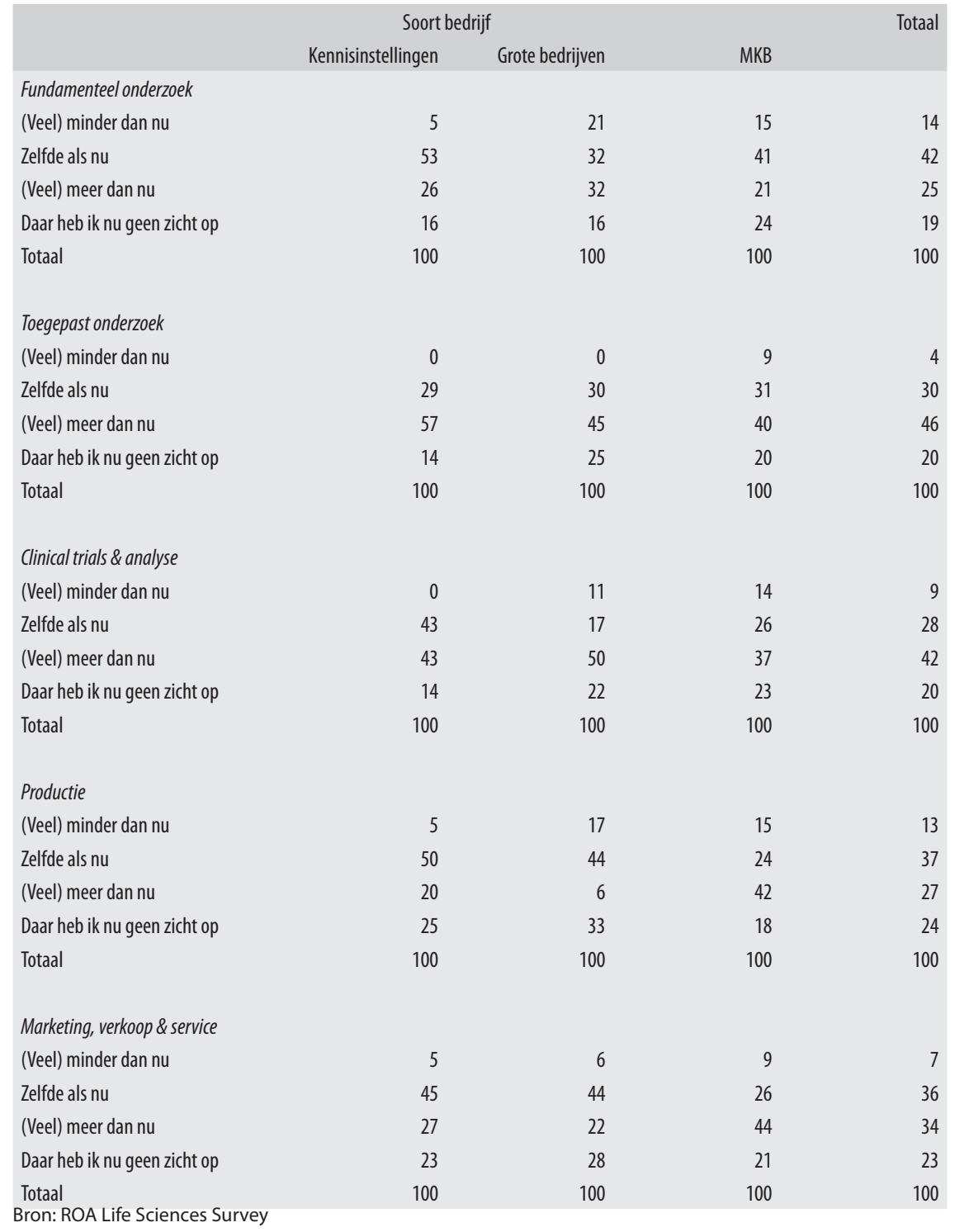


